\title{
Aerosol and precipitation chemistry measurements in a remote site in Central Amazonia: the role of biogenic contribution
}

\author{
T. Pauliquevis ${ }^{1}$, L. L. Lara ${ }^{2}$, M. L. Antunes ${ }^{3}$, and P. Artaxo ${ }^{4}$ \\ ${ }^{1}$ Departamento de Ciências Exatas e da Terra, Universidade Federal de São Paulo, Diadema, SP, Brazil \\ ${ }^{2}$ Faculdade de Engenharia, Arquitetura e Urbanismo - UNIMEP, Santa Barbara, SP, Brazil \\ ${ }^{3}$ Campus Experimental de Sorocaba, Universidade Estadual Paulista, Sorocaba, SP, Brazil \\ ${ }^{4}$ Instituto de Física, Universidade de São Paulo, São Paulo, SP, Brazil
}

Correspondence to: T. Pauliquevis (theotonio@gmail.com)

Received: 30 May 2007 - Published in Atmos. Chem. Phys. Discuss.: 3 August 2007

Revised: 13 January 2012 - Accepted: 8 April 2012 - Published: 7 June 2012

\begin{abstract}
In this analysis a 3.5 years data set of aerosol and precipitation chemistry, obtained in a remote site in Central Amazonia (Balbina, ( $1^{\circ} 55^{\prime} \mathrm{S}, 59^{\circ} 29^{\prime} \mathrm{W}, 174 \mathrm{~m}$ a.s.l.), about $200 \mathrm{~km}$ north of Manaus) is discussed. Aerosols were sampled using stacked filter units (SFU), which separate fine $(d<2.5 \mu \mathrm{m})$ and coarse mode $(2.5 \mu \mathrm{m}<d<10.0 \mu \mathrm{m})$ aerosol particles. Filters were analyzed for particulate mass $(\mathrm{PM})$, Equivalent Black Carbon $\left(\mathrm{BC}_{\mathrm{E}}\right)$ and elemental composition by Particle Induced X-Ray Emission (PIXE). Rainwater samples were collected using a wet-only sampler and samples were analyzed for $\mathrm{pH}$ and ionic composition, which was determined using ionic chromatography (IC). Natural sources dominated the aerosol mass during the wet season, when it was predominantly of natural biogenic origin mostly in the coarse mode, which comprised up to $81 \%$ of $\mathrm{PM}_{10}$. Biogenic aerosol from both primary emissions and secondary organic aerosol dominates the fine mode in the wet season, with very low concentrations (average $2.2 \mu \mathrm{g} \mathrm{m}^{-3}$ ). Soil dust was responsible for a minor fraction of the aerosol mass (less than $17 \%$ ). Sudden increases in the concentration of elements as $\mathrm{Al}, \mathrm{Ti}$ and $\mathrm{Fe}$ were also observed, both in fine and coarse mode (mostly during the April-may months), which we attribute to episodes of Saharan dust transport. During the dry periods, a significant contribution to the fine aerosols loading was observed, due to the large-scale transport of smoke from biomass burning in other portions of the Amazon basin. This contribution is associated with the enhancement of the concentration of $\mathrm{S}, \mathrm{K}, \mathrm{Zn}$ and $\mathrm{BC}_{\mathrm{E}}$. Chlorine, which is commonly associated to sea salt and also to biomass burning emissions, presented higher concentration not only during
\end{abstract}

the dry season but also for the April-June months, due to the establishment of more favorable meteorological conditions to the transport of Atlantic air masses to Central Amazonia. The chemical composition of rainwater was similar to those ones observed in other remote sites in tropical forests. The volume-weighted mean (VWM) pH was 4.90. The most important contribution to acidity was from weak organic acids. The organic acidity was predominantly associated with the presence of acetic acid instead of formic acid, which is more often observed in pristine tropical areas. Wet deposition rates for major species did not differ significantly between dry and wet season, except for $\mathrm{NH}_{4}^{+}$, citrate and acetate, which had smaller deposition rates during dry season. While biomass burning emissions were clearly identified in the aerosol component, it did not present a clear signature in rainwater. The biogenic component and the long-range transport of sea salt were observed both in aerosols and rainwater composition. The results shown here indicate that in Central Amazonia it is still possible to observe quite pristine atmospheric conditions, relatively free of anthropogenic influences.

\section{Introduction}

Tropical biogenic atmospheric aerosols play important roles in climate and atmospheric chemistry: they scatter sunlight, provide condensation nuclei for cloud droplets (Roberts et al., 2001, 2002) and participate in heterogeneous chemical reactions (Andreae and Crutzen, 1997; Artaxo et al., 1998; Andreae, 2007; Martin et al., 2010a,b). Large areas of the 
tropics are covered with rain forests that act as source regions of biogenic particles and trace gases to the global atmosphere (Andreae, 2007; Jaenicke, 2005, Schneider et al., 2011). The properties of atmospheric biological particles have been studied in only a few studies with measurements of their physical and chemical properties (Artaxo and Hansson, 1995; Artaxo et al., 1988; Guyon et al., 2003, Pöschl et al., 2010). Baseline knowledge of the source strengths, properties and processes of natural biogenic aerosols is necessary to correctly assess present-day burdens, direct radiative forcing and nutrient cycling in tropical regions (Martin et al., 2010a, b; Jaenicke, 2005).

Tropical rainforests depend on efficient nutrient recycling to maintain its primary production levels (Davidson and Artaxo, 2004). Usually residing over poor soils (Vitousek and Sanford, 1986), the tropical rainforest environment has become adapted to this condition along its own evolutionary history, developing a system that provides a stable equilibrium to the rainforest ecosystem (Salati and Vose, 1984). Atmosphere-biosphere interactions are an important component of tropical nutrient cycling. The correct understanding of processes that modulate atmospheric composition and the deposition of trace elements and nutrients is important to infer the role of atmospheric processes in nutrient cycling (Davidson et al., 2012; Mahowald et al., 2005).

In spite of the high deforestation rates in Southeastern Amazonia in the last 3 decades most of the forested area is still preserved ( $\sim 83 \%$ of the original forest area). Deforestation is not spread over the entire Amazon basin but concentrated in the so-called "deforestation arc" region mostly in the Southeast/Southwest portion of the Amazon Basin. This region is subject to intense biomass-burning emissions every year during the dry season (Artaxo et al., 2002; Silva-Dias et al., 2002). The intensity of these emissions is a complex function of socioeconomic pressures for new agricultural areas, climatic effects and governance policies (Bowman et al., 2009, 2011; Morton et al., 2008; Koren et al., 2007).

The central and western portions of the Amazon rainforest are mostly well preserved with small rates of deforestation. The state of Amazonas, the largest in Brazil comprising about 1.6 million $\mathrm{km}^{2}$ with a population of 3484000 inhabitants, where this work was conducted, has only $2 \%$ of deforested area. Under such pristine conditions, natural sources and sinks of gases and aerosols play the most important roles in controlling atmospheric composition, especially during the wet season (Davidson et al., 2012).

Previous studies indicate that vegetation is the most important source of natural biogenic particles in pristine areas in the Amazon Basin (Artaxo et al., 1988, 1990, 1998; Graham et al, 2003a, b; Martin et al., 2010a,b; Pöschl et al., 2010). Natural biogenic aerosol comprises up to $80 \%$ of $\mathrm{PM}_{10}$ aerosol mass, with most of the mass (approx. 70\%) in the coarse mode fraction (Echalar et al., 1998; Gerab et al., 1998; Gilardoni et al., 2011). Biogenic particles consist of particles primarily emitted by the vegetation (e.g. bacteria, fungi, spores, and plant and insects debris), mainly in coarse mode $\left(d_{p}>2.5 \mu \mathrm{m}\right)$ (Artaxo and Hansson, 1995; Jaenicke, 2005), and sub-micron particles as a product of gas-to-particle conversion of biogenic trace gases emitted naturally by the vegetation (Pöschl et al., 2010; Martin et al., 2010a, b; Chen et al., 2009; Hoffmann et al, 1997, 1998; Claeys et al., 2004). Soil dust observed at Central Amazonia is a combination of local emission and the long range transport of Saharan dust, which takes place mostly between February and May (Ansmann et al., 2009; Talbot et al., 1990; Swap et al., 1992, 1996; Formenti et al., 2001).

The fine mode fraction is strongly associated with the production of Secondary Organic Aerosols (SOA) that comprises about $80 \%$ of $\mathrm{PM}_{1.0}$ (Martin et al., 2010a, b; Pöschl et al., 2010). Most of these are produced from oxidation of volatile organic compounds (VOCs) (Chen et al., 2009).

Precipitation is among the most important sink pathways for atmospheric compounds. It acts as an external input of nutrients to the forest environment, and is also an important pathway in nutrient recycling in tropical areas. Due to this linkage, rainwater composition is influenced by airborne aerosol particles and trace gas chemistry. Rainwater composition is influenced by atmospheric chemistry in two ways. The first one is on the formation of cloud drops, when scavenged aerosol particles act as cloud condensation nuclei (CCN), contributing to the composition of the initial drop. The aqueous environment of the drop is also adequate for the absorption of soluble trace gases, working as a catalytic factor to many chemical reactions possible only in aqueous media (Scott and Laulainen, 1979; Hegg et al., 1984; Hegg and Hobbs, 1988), and biotransformation by microorganisms (Amato et al., 2007). The second removal process takes place when precipitation begins. Falling raindrops collide with airborne aerosols below cloud base, collecting these particles and adding matter to raindrops (Pruppacher and Klett, 1997). This mechanism of aerosol removal is one of the major processes by which the atmosphere is cleansed. The final result of rainwater chemistry is the combination of these two processes named rainout (in-cloud) and washout (below-cloud)

Previous studies of rainwater composition in Central Amazonia (Stallard and Edmond 1981; Andreae et al., 1990; Williams et al., 1997; Forti et al., 2000) reported small or even no anthropogenic influence in rainwater composition. These studies have characterized the composition of (natural) rainfall by its low ionic concentration of major species, low acidity (pH ranging from 4.7 to 5.3) and an important contribution of organic acids (mainly acetic and formic acid) to the acidity profile of precipitation, a common feature in remote sites (Andreae et al., 1988; Keene et al., 1983; Sanhueza et al., 1991; Khare et al., 1999). In the aerosol phase, previous studies of aerosol composition in remote sites in Amazonia (Artaxo et al., 1988, 1990, 1998) showed that natural biogenic emissions are predominant in the aerosol mass during the wet season, and subject to some influence of biomass 


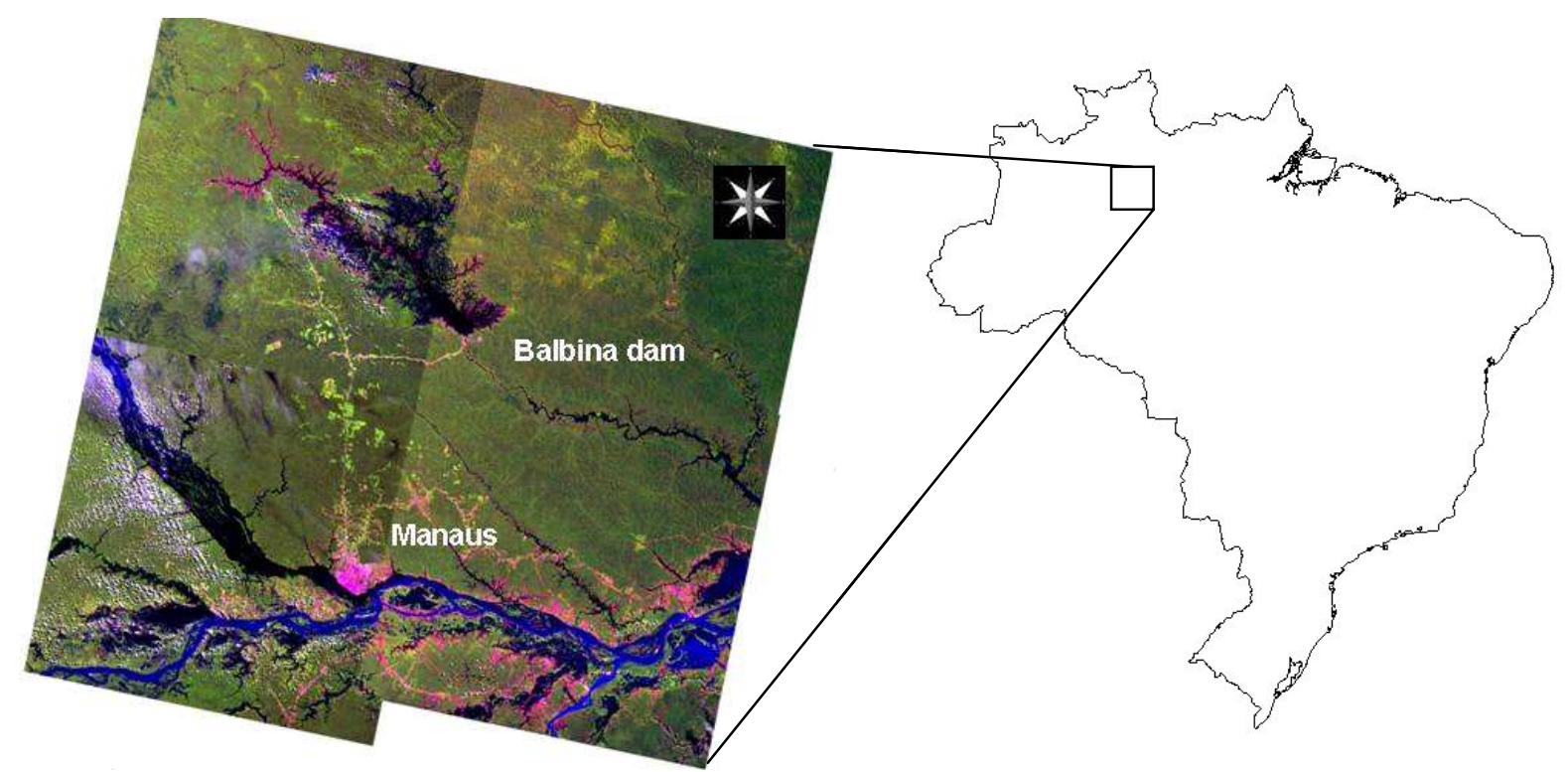

Fig. 1. Landsat image of the sampling site area. The city of Manaus (population 1700000) is shown in the low central portion of the figure. Balbina is located about $200 \mathrm{~km}$ North from Manaus in a preserved area free of deforestation and under influence of natural emissions of gases and aerosols.

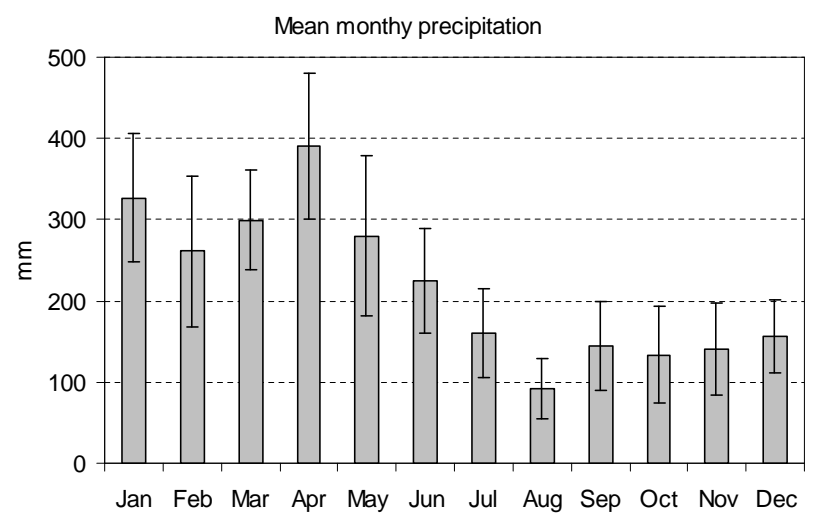

Fig. 2. Average monthly precipitation in the Balbina region during the period 1998-2001. Data were obtained from four hydrological stations operated by the Brazilian National Water Agency (http:// hidroweb.ana.gov.br). Error bars correspond to standard deviation of data.

burning emissions during the dry season, depending on the distance from sources.

In this study we carried out a 3.5 years measurement of aerosol and precipitation chemistry in a remote site in Central Amazonia. The main objective was to investigate the aerosol - precipitation chemistry linkage under pristine conditions, with the aim of understanding how important the influence of aerosol composition is on rainwater chemistry in remote continental areas. It is important to emphasize that this study does not deal with aerosol composition in areas heavily im- pacted by biomass burning such as Rondonia, Alta Floresta or Southeast Amazonia. Biomass burning effects on aerosol and rainwater composition were characterized in detail during the LBA/SMOCC campaign (Fuzzi et al., 2007; Trebs et al., 2005).

\subsection{Sampling location}

\subsection{Description of the sampling site}

Balbina, the sampling site $\left(1^{\circ} 55^{\prime} \mathrm{S}, 59^{\circ} 29^{\prime} \mathrm{W}, 174 \mathrm{~m}\right.$ a.s.l.), is a small village located about $200 \mathrm{~km}$ North of Manaus (see Fig. 1). The population density of the region is only 0.49 inhabitant $\mathrm{km}^{-2}$ and there is no significant agricultural activity in its surroundings, with almost no local biomass burning activity. It is close to the lake of the Balbina large hydroelectric plant, a lake which covers approximately 240000 ha.

\subsection{Precipitation climatology and site characterization}

Figure 2 shows the annual cycle of monthly accumulated precipitation for the region around the sampling site between 1998-2001 (data available at http://hidroweb.ana.gov.br). From the figure it is possible to observe large monthly variability in precipitation and that Central Amazonia wet season takes place from January to May, and dry season from August to November. June, July and December are transition months. Total annual precipitation was $2530 \pm 330 \mathrm{~mm}$ for this period. Variability in inter-annual precipitation characteristics are mainly correlated with equatorial Pacific and Atlantic sea surface temperature (SST), which strongly modulate the 
intensity and the onset of the wet season in Central Amazon (Marengo et al., 2001). The South Atlantic Convergence Zone also plays a role in some precipitation events (Carvalho et al., 2004).

Balbina is mostly influenced by eastern air masses associated to the trade winds circulation. From the tropical Atlantic ocean, air masses travel more than $1000 \mathrm{~km}$ over pristine primary tropical rainforest before reaching the site. It makes this region an excellent choice to observe natural background chemical conditions for aerosol and precipitation, in particular during the wet season when there are no biomass burning reaching the site. Several previous works dealing with the natural component of aerosols were published based on data collected at Balbina (e.g. Zhou et al., 2002; Graham et al., 2003a, b; Rissler et al., 2004). During the dry season (August-November) the site is subject to the large-scale transport of biomass-burning aerosols that typically occurs in other portions of the basin. This signal, which has significant influences in the fine mode concentration during the drier months, was detected and quantified in our analysis, and is described in detail latter.

\section{Experimental}

\subsection{Aerosol sampling and analysis}

Aerosol sampling at Balbina was operated continuously from October 1998 to March 2002. Fine and coarse mode aerosol particles were collected using stacked filter units (SFU) (Hopke et al., 1997) fitted with a $\mathrm{PM}_{10}$ inlet. The SFU collects particles on $47 \mathrm{~mm}$ diameter polycarbonate membrane filters. An $8 \mu \mathrm{m}$ pore size filter collects coarse particles $\left(2.5<d_{p}<10 \mu \mathrm{m}\right)$ while a $0.4 \mu \mathrm{m}$ pore size filter collects fine particles $\left(d_{p}<2.5 \mu \mathrm{m}\right)$. The flow rate was typically 16 liters per minute, and sampling time varied from 2 to 5 days.

Elemental concentrations for the SFU filters samples were obtained by Particle-Induced X-Ray Emission (PIXE) analysis (Gerab et al., 1998). It was possible to determine the concentrations of up to 18 elements ( $\mathrm{Mg}, \mathrm{Al}, \mathrm{Si}, \mathrm{P}, \mathrm{S}, \mathrm{Cl}, \mathrm{K}$, $\mathrm{Ca}, \mathrm{Ti}, \mathrm{V}, \mathrm{Cr}, \mathrm{Mn}, \mathrm{Fe}, \mathrm{Ni}, \mathrm{Cu}, \mathrm{Zn}, \mathrm{Br}$ and $\mathrm{Pb}$ ). A dedicated 5SDH tandem Pelletron accelerator facility at the University of Sao Paulo LAMFI (Laboratório de Análise de Materiais por Feixes Iônicos) was used for the PIXE analyses. Detection limits were typically $5 \mathrm{ng} \mathrm{m}^{-3}$ for elements in the range $13<Z<22$ and $0.4 \mathrm{ng} \mathrm{m}^{-3}$ for elements with $\mathrm{Z}>22, \mathrm{Z}$ being the atomic number. Precision of elemental concentration measurements is typically better than $7 \%$, reaching up to $20 \%$ for elements with concentrations near the detection limit (Gerab et al., 1998).

Mass concentrations were obtained through gravimetric analysis. Both fine and coarse filters from the SFU were weighed before and after sampling in a Mettler M3 electronic microbalance with $1 \mu \mathrm{g}$ sensitivity. Before weighing, filters were kept for $24 \mathrm{~h}$ at $50 \%$ relative humidity and $20^{\circ} \mathrm{C}$. Elec- trostatic charges were controlled by means of ${ }^{210}$ Po radioactive sources. Detection limit for the aerosol mass concentration is $0.3 \mu \mathrm{g} \mathrm{m}^{-3}$. Precision is estimated at about $10 \%$. Equivalent black carbon $\left(\mathrm{BC}_{\mathrm{E}}\right)$ concentration on the fine and coarse fraction of the SFU filters was obtained by a light reflectance technique. The optical absorption of the polycarbonate filters was analyzed by a smoke stain reflectometer that measures light attenuation by the aerosol particles. The instrument was calibrated using standard Monarch "soot" carbon deposited in gravimetrically analyzed Nuclepore filters (Martins et al., 1998a, 1998b). The term "equivalent" black carbon is used in this work following suggestions from several studies indicating the mixed presence of several types of absorbing aerosols, as well as the so-called "brown carbon", a light absorbing aerosol that is not elemental carbon (Andreae and Gelencsér, 2006).

\subsection{Rainwater sampling and analysis}

The precipitation sampling was operated from April 1998 to December 2001, with interruptions between June 1999February 2000 and February-June 2001. A set of 87 samples was collected, representing $52 \%$ of the total precipitation $(5673 \mathrm{~mm})$ for the sampling period. Samples were collected using automated wet-only rainwater collectors, in high-density polyethylene bottles, which had been previously rinsed with miliQ water. Immediately after its collection in the field, Thymol was added to preserve samples from microbial growth and the resulting deterioration of organic acids and nitrogen species (Gillett and Ayers, 1991). In order to check the quality of the data set, Ionic Balance (IB) was used as the key parameter to identify outliers, in agreement with WMO recommendations (WMO, 2004).

The $\mathrm{pH}$ of each sample was measured twice: immediately after sampling (Cole Parmer portable $\mathrm{pH}$ meter model CON 10) and later in the laboratory (Orion pH meter model EA940 with a glass electrode) using low ionic strength buffer solutions (Orion application solution). For calibration, two standard solutions with $\mathrm{pH} 4.00$ and 7.00 were used. The resolution of the measurement was $0.01 \mathrm{pH}$ units. Anions and cations concentrations were determined at the Isotopic Ecology Laboratory, CENA - USP (Center for Nuclear Energy in Agriculture of University of São Paulo - Brazil), with a DIONEX DX600 ion chromatograph (IC). The system used a gradient pump (GP40), with electrochemical (ED40) and conductivity detectors (CD20) for anions and cations, respectively, and a DIONEX IonPac AS-11 and CS-12 with pre-columns DIONEX AG-11 and CG-12. The eluents were $\mathrm{NaOH}$ and MSA for anions and cations, respectively. Ionic standards (Ultra-Science) were used for IC calibration. Detection limits were $0.05 \mu \mathrm{m}$, the precision was within an interval of $3 \%$ and the accuracy was $0.01 \mu \mathrm{Ml}^{-1}$. It was possible to determine concentrations of $\mathrm{Na}^{+}, \mathrm{NH}_{4}^{+}, \mathrm{K}^{+}, \mathrm{Mg}^{2+}$, $\mathrm{Ca}^{2+}, \mathrm{Cl}^{-}, \mathrm{NO}_{3}^{-}, \mathrm{SO}_{4}^{2-}, \mathrm{F}^{-}$, acetate $\left(\mathrm{CH}_{3} \mathrm{COO}^{-}\right)$, formate 
$\left(\mathrm{HCOO}^{-}\right), \mathrm{NO}_{2}^{-}, \mathrm{Br}^{-}$, oxalate $\left(\mathrm{C}_{2} \mathrm{O}_{4}^{2-}\right)$, citrate $\left(\mathrm{C}_{6} \mathrm{H}_{5} \mathrm{O}_{7}^{3-}\right)$, $\mathrm{PO}_{4}^{3-}$, and Dissolved Inorganic Carbon (DIC).

\subsection{Data analysis}

Data analysis procedures have to deal with the fact that the concentration of ionic species in rainwater is dependent not only on the amount of the component, but also on storm size. Larger storms tend to dilute ionic concentrations while smaller storms tend to be more concentrated. To avoid this effect, the results for precipitation are presented in the form of Volume Weighted Mean (VWM). The VWM concentration of the $j$-th ionic species is defined as

$$
(\mathrm{VWM})_{j}=\frac{\sum_{i=1}^{N} \mathrm{C}_{i, j} \mathrm{v}_{i}}{\sum_{i=1}^{N} \mathrm{v}_{i}}
$$

where $\mathrm{v}_{i}$ is the storm size in the $i$-th sample, $\mathrm{C}_{i, j}$ is the concentration of the $j$-th ionic species in the $i$-th sample, and $N$ is the total number of samples. The numerator can be understood as the total deposition for the $j$-th ion during the sampling period.

In order to identify and remove the possible influence of marine contribution, the non-seasalt (nss) component for some selected compounds was calculated. The determination of this value was calculated considering the ionic proportion to $\mathrm{Na}^{+}$in seawater (Riley, 1975), and assuming that $\mathrm{Na}^{+}$ concentration is exclusively due to marine emissions. Thus, the nss contribution for the species $\mathrm{X}$ was determined using Eq. (2)

$$
[X]_{\text {nss }}=[X]_{\text {rainwater }}-[\mathrm{X} / \mathrm{Na}]_{\text {seawater }} \times[\mathrm{Na}]_{\text {rainwater }} .
$$

In order to separate the different aerosol and rainwater components, Absolute Principal Factor Analysis (APFA) was applied to the measurements database analyzing data variability. The APFA procedure was used to estimate the portion of the different aerosol components (using elemental composition) and precipitation composition (using ionic deposition rates) (Hopke, 1985; Switlicki et al., 1996). APFA offers the possibility of obtaining a quantitative component profile instead of only a qualitative factor loading matrix as in traditional applications of factor analysis, and has been successfully applied to aerosol studies in the Amazon Basin (e.g. Echalar et al., 1998; Maenhaut et al., 2002). The absolute source profile helps in the identification of the factors and can be used to compare the factor composition with the presumed source composition. The absolute profile is determined by calculating a linear regression between each measured concentration (for each chemical compound) and the normalized contribution of each component for each sample (the "socalled factor scores"), a result provided by traditional Factor

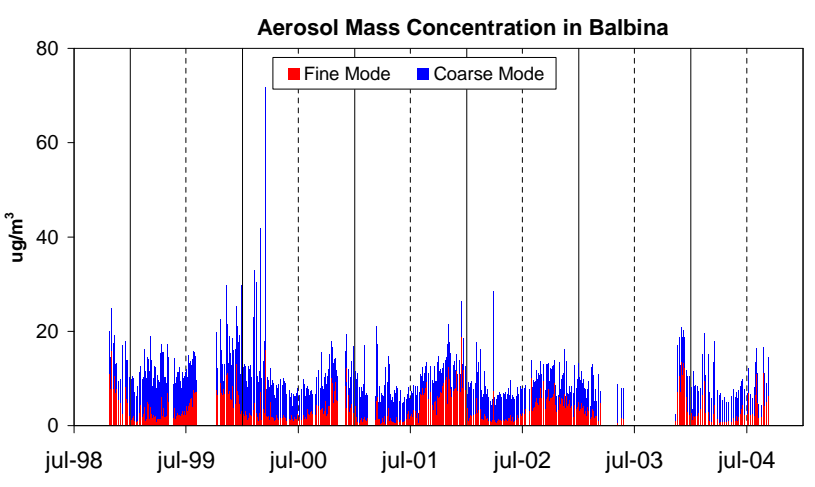

Fig. 3. The aerosol mass concentration time series at Balbina from October 1998 to September 2004. Concentrations are shown separately for Fine Particulate Mass (FPM, $\left.d_{p}<2.5 \mu \mathrm{m}\right)$ and Coarse Particulate Mass (CPM, $\left.2.5 \mu \mathrm{m}<d_{p}<10 \mu \mathrm{m}\right)$.

Analysis (FA) after VARIMAX rotation. The result of the linear regression allows for determining quantitatively the absolute contribution of each extracted component for each chemical compound (Switlicki et al., 1996).

\section{Results}

\subsection{Aerosol measurements}

The time series of fine and coarse mode aerosol mass concentrations is shown in Fig. 3. The fine mode mass concentration $\left(\mathrm{PM}_{2.5}\right)$ is shown in red, while the coarse mode fraction is shown in blue. The sum of both components is the $\mathrm{PM}_{10}$ aerosol mass concentration. The observed average aerosol mass concentration was very low, amongst the lowest values observed in remote continental areas. $\mathrm{PM}_{2.5}$ concentrations in the wet season were as low as $2.2 \mu \mathrm{g} \mathrm{m}^{-3}$. During the dry season, it was possible to observe some influence of long range biomass burning plumes that increased $\mathrm{PM}_{2.5}$ to $6.2 \mu \mathrm{g} \mathrm{m}^{-3}$. The typical annual mean of $\mathrm{PM}_{10}$ concentration of $11 \mu \mathrm{g} \mathrm{m}^{-3}$ experienced an increase during the dry season due to an enhancement of the concentration in the fine mode. The coarse mode concentration mostly associated with primary biogenic particles is rather constant along the year at about $7 \mu \mathrm{g} \mathrm{m}^{-3}$. It is also possible to observe in Fig. 3 some significant episodic enhancements in the coarse particle mass. These episodes were associated with dust transport from the Sahara desert, documented in several studies (Formenti et al., 2001; Swap et al., 1992, 1996; Koren et al., 2006; Ansmann et al., 2009; Baars et al., 2011; Ben-Ami et al., 2010).

Time series of fine and coarse mode $\mathrm{BC}_{\mathrm{E}}$ concentration are shown in Fig. 4. The annual average fine mode $\mathrm{BC}_{\mathrm{E}}$ concentrations were $170 \mathrm{ng} \mathrm{m}^{-3}$, which is a low value for a continental region. The fine mode $\mathrm{BC}_{\mathrm{E}}$ concentration (Fig. 4a) had a similar seasonal variability as the $\mathrm{PM}_{2.5}$ concentrations and 
is a combination of two components: the natural optical absorption of fine mode primary aerosol particles and the optical absorption by the biomass burning component. The $\mathrm{BC}_{\mathrm{E}}$ concentration in the coarse mode aerosols, with an average of $50 \mathrm{ng} \mathrm{m}^{-3}$, is shown in the Fig. 4b. This component represents absorbing aerosols in the primary biogenic particles in the coarse mode fraction and is essentially constant throughout the sampling period. This suggests that the coarse mode natural biogenic absorbing component is not affected significantly during the dry season. This is in agreement with other studies that point to a natural biogenic contribution to absorbing aerosols (Guyon et al., 2003; Andreae and Gelencsér, 2006; Rizzo et al., 2011).

Two large aerosol studies with intensive sampling campaigns were carried out in Balbina as part of LBA-CLAIRE (Cooperative LBA Airborne Regional Experiment) (Andreae et al., 2002). The first CLAIRE intensive sampling campaign was carried out in March-April 1998 (mid-wet season), and the second in July 2001 (wet-to-dry season transition). A significant difference in mean particle number concentration was observed. Zhou et al. (2002) reported mean concentration of $590 \pm 440 \# / \mathrm{cm}^{-3}$ for the wet season 1998 experiment, a significantly lower value than Rissler et al. (2004) reported for the July 2001 sampling campaign, $1140 \pm 690$ $\# / \mathrm{cm}^{-3}$. Nevertheless, the number of fire hotspots during July 2001 was only 9 hotspots for the whole Amazonas state, which is evidence that local/regional contribution was very small or negligible, and that pollution plumes from distant sources were probably responsible for such an enhancement in particle number concentration. Figure 5 shows the spatial distribution of fire hotspots observed from July to November in 2001 in Brazil. In July the Amazonas state was almost free of fire spots. However, from August to November many hotspots were observed along the Amazonas River (southeast of Balbina). As such, some regional contribution is expected to reach Balbina, influencing the aerosol composition during the most intense periods of biomass burning activity. To test this hypothesis, backward air masses trajectories reaching Balbina were calculated for a representative day. This result is shown in Fig. 8 for 25 September 2001, at the peak of the biomass-burning season. Back trajectories were calculated using the Hysplit model. The trajectories show that for a variety of air mass levels reaching Balbina (100, 1000 and $2000 \mathrm{~m}$ a.g.1.) all of the trajectories passed over the Amazonas river path, where fire hotspots were observed, and that probably the biomass-burning influence detected in Balbina is due to the transport of plumes originated in this region during the biomass burning season.

A summary of average elemental concentrations measured in aerosols at Balbina is shown in Table 1, for fine and coarse mode aerosols. Averages were separated as annual, first and second semester means. In spite that separation by semester is affected by the transition months (as described in Sect. 2), the first and the second semester are representative of wet and dry season regimes, respectively. Aerosol mass is dominated
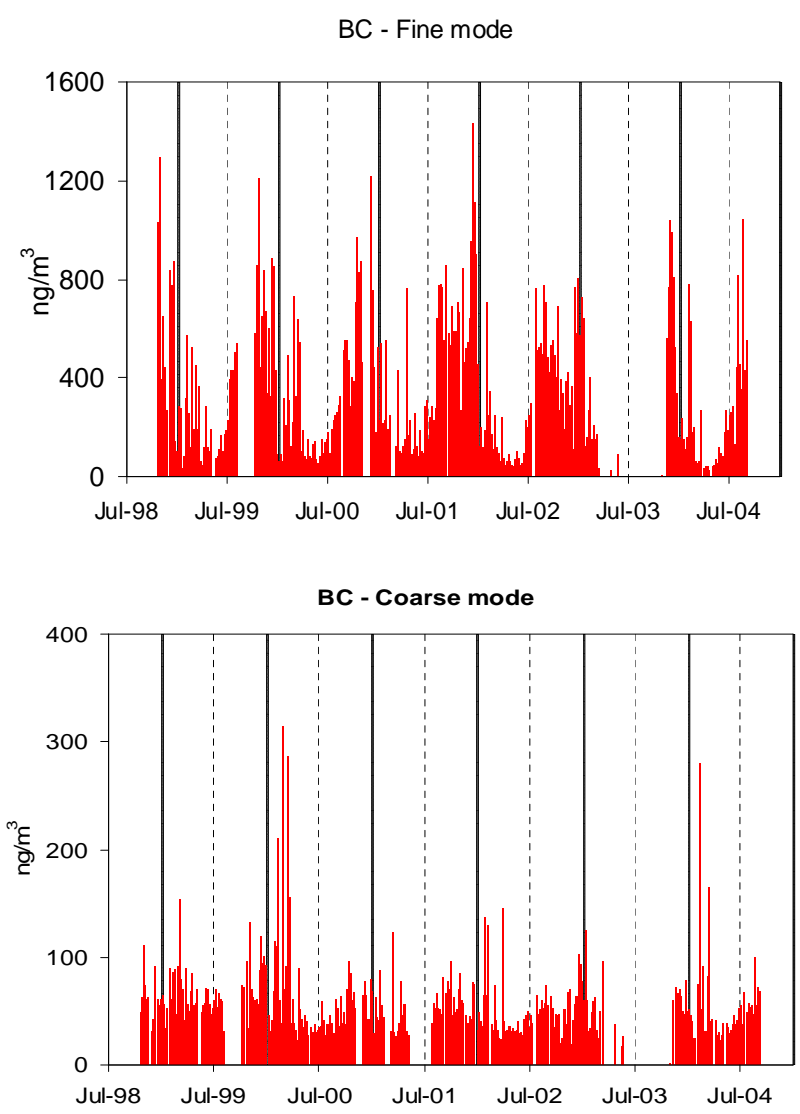

Fig. 4. The equivalent black carbon $\left(\mathrm{BC}_{\mathrm{E}}\right)$ concentration observed in Balbina for (a) fine mode (top) and (b) coarse mode (bottom) during the same period presented in Fig. 2. Mean concentrations were $170 \pm 180 \mathrm{ng} \mathrm{m}^{-3}$ for the fine mode and $50 \pm 40 \mathrm{ng} \mathrm{m}^{-3}$ for the coarse mode. Note the increase in fine mode concentration during dry periods synchronized with the increase in fine particulate mass. This behavior is not observed in coarse mode, which is not influenced by the biomass-burning emissions.

by the coarse mode component over fine particles. $\mathrm{BC}_{\mathrm{E}}$ concentration was predominantly in the fine mode, with higher values during the 2 nd semester, corresponding to the dry season. The elements $\mathrm{S}, \mathrm{K}$ and $\mathrm{Zn}$ also experienced higher concentrations during the dry season. Sulfur concentrations, on the order of $100-300 \mathrm{ng} \mathrm{m}^{-3}$, are low in Central Amazonia. Monthly means of particulate mass, $\mathrm{BC}_{\mathrm{E}}$ and elemental concentrations are shown in Fig. 6. Plots are separated in coarse mode in the left and fine in the right side, and the analysis of these data allows characterizing the typical annual cycle of each measured component, as well as the CPM, FPM and $\mathrm{BC}_{\mathrm{E}}$.

\section{Coarse and fine particulate mass}

The variation of monthly means of CPM was quite small, and a minimum concentration was observed in August 

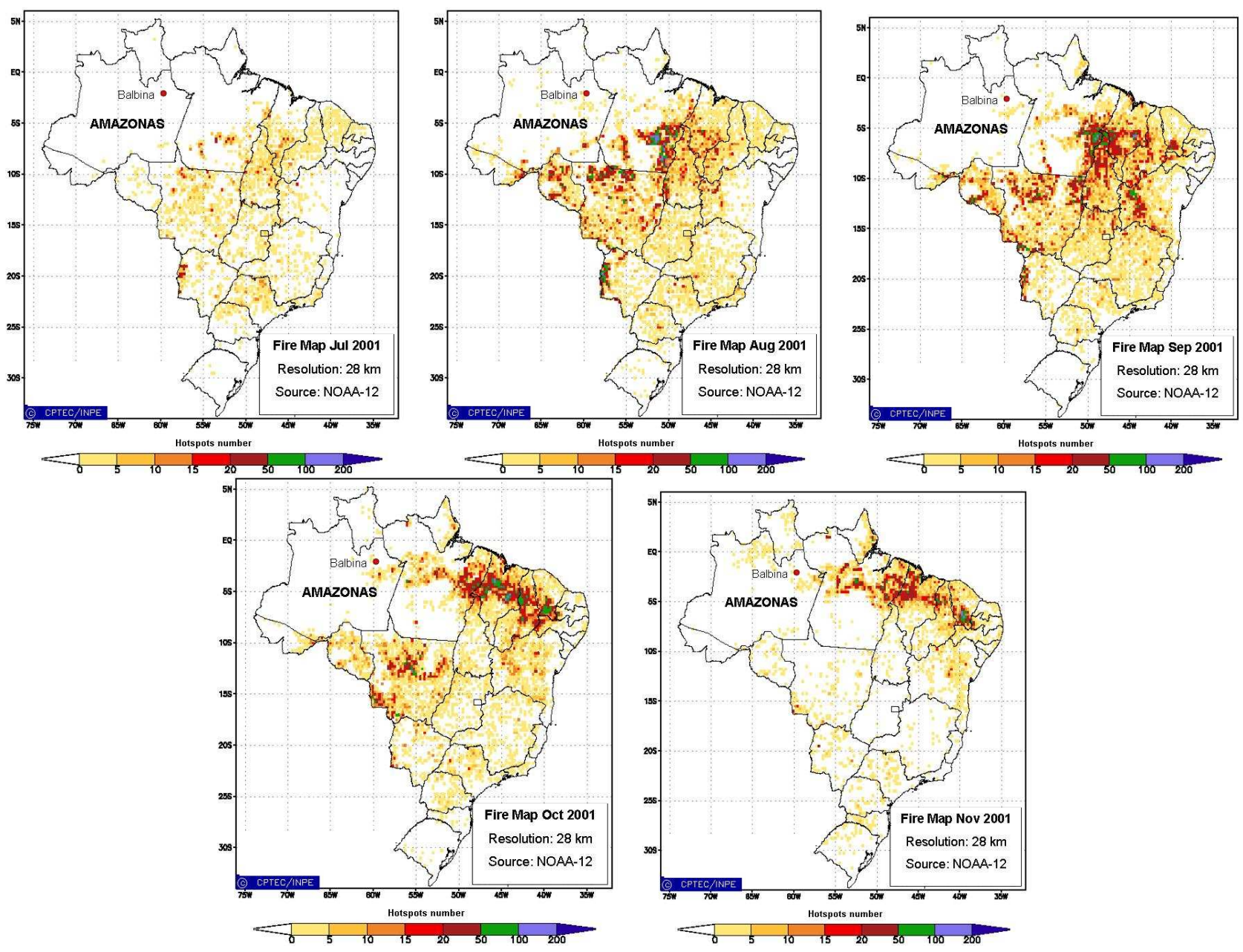

Fig. 5. Spatial distribution of fire hotspots in Brazil for Jul-Nov in 2001. The Amazonas state had not an important contribution of biomassburning emissions, in spite of an increase (mainly southeast from Balbina) of hotspots after August. Source: CPTEC/INPE (at http://www. cptec.inpe.br/products/queimadas/queimamensaltotal.html\#).

(4000 $\mathrm{ng} \mathrm{m}^{-3}$ ). In fact, for the remaining months it varied within $6000-8000 \mathrm{ng} \mathrm{m}^{-3}$, which is a rather small range. This is a completely different behavior of FPM, which presented a clear seasonal variation. FPM presented a significant increase in its concentration for the period July-November, a slight reduction in December and a steep reduction in January. This pattern is compatible with the annual cycle of precipitation, shown in Fig. 2.

\section{$\mathrm{BC}_{\mathrm{E}}, \mathrm{K}, \mathrm{S}$ and $\mathrm{Zn}$}

In the coarse mode, two patterns of annual cycles were observed. $\mathrm{Zn}$ and $\mathrm{K}$ presented an almost constant level throughout the year, whereas $\mathrm{BC}_{\mathrm{E}}$ and $\mathrm{S}$ presented some seasonality. $\mathrm{BC}_{\mathrm{E}}$ and $\mathrm{S}$ typically increased their concentration after July, with a reduction in December. When comparing the difference of average $\mathrm{BC}_{\mathrm{E}}$ concentrations of the wet sea- son $\left(48 \pm 8 \mathrm{ng} \mathrm{m}^{-3}\right)$ with the dry season $\left(53 \pm 5 \mathrm{ng} \mathrm{m}^{-3}\right)$ it is possible to see that it is not statistically significant $(p<$ 0.01 ). Moreover, it is possible to see that (except for October) all the monthly means of the dry season were smaller than the concentrations of January and February. Thus, it is likely that the annual cycle of $\mathrm{BC}_{\mathrm{E}}$ in the coarse mode is more related to natural processes (e.g. absorption component of biogenic aerosols, see Rizzo et al., 2011) than biomassburning influences.

$\mathrm{BC}_{\mathrm{E}}$ variations in the fine mode followed the FPM pattern. During the wet season, when natural sources of particles dominate the concentration, it represents the absorbing component of biogenic of aerosols (Pöschl et al., 2010; Martin et al., 2010a, b; Andreae and Galencsér, 2006). During the dry season the increase in $\mathrm{BC}_{\mathrm{E}}$ concentration is due to the influence of the large scale transport of biomass burning plumes 
from other regions in the Amazon Basin (Soto-Garcia et al., 2011).

\section{Ti, Fe, Al, Si and Ca}

These elements are usually employed as tracers for soil dust aerosols. Monthly means of these elements presented a similar behavior both in fine and coarse modes. Typically, the monthly means of these elements was consistently larger in $\mathrm{Jan} / \mathrm{Feb} / \mathrm{Mar} / \mathrm{Apr}$, followed by a reduction in May/Jun and then a moderate increase until December. However, as shown in the discussion of the Principal Component Analysis, it was in April and May that we observed bursts of this elements. We attribute it to the transport of Saharan dust, which has been shown to be more likely to happen during these months (Baars et al., 2011).

\section{Cl}

Most of $\mathrm{Cl}$ content was present in the coarse mode fraction, as can be seen in Fig. 6 (note the different vertical scales for each size fraction). Concentration in the coarse mode was about 15 times greater than the fine mode. The monthly means presented a quite broad variation, presenting two maxima throughout the year. During the rainy months $\mathrm{Cl}$ concentrations reached the highest value. With respect to the dry season, when fine and coarse modes varied the concentration of $\mathrm{Cl}$ varied quite similarly, with maximum in October. Potential sources of $\mathrm{Cl}$ in Balbina are the marine contribution (seasalt aerosols advected from the Atlantic as $\mathrm{NaCl}$ ) and biomass burning (generally as $\mathrm{KCl}$ ) during the dry season. Thus, a possible explanation for this behavior could be that the transport of seasalt aerosols during the wet season was the most important source for $\mathrm{Cl}$, and that during the dry season a combination of both sources was responsible by the $\mathrm{Cl}$ budget in the atmosphere. Nevertheless, in spite that biomass-burning was clearly detected during the dry season in this study, it is possible that at least for $\mathrm{Cl}$ it was not important at Balbina. In fact, $\mathrm{Cl}$ presented low concentrations during the dry season. Further, in the factor analysis, it was not possible to observe a component connecting $\mathrm{K}$ and $\mathrm{Cl}$, as shown in the upcoming analysis. Thus, we state that $\mathrm{Cl}$ budget is predominantly associated with the strength of the marine contribution, and that other contributions are minor.

\section{Factor analysis}

Factor analysis was used to identify common variability between the different trace elements in the data set. With the goal of a better separation of dry and wet seasons influences, the whole data set was analyzed separately for the 1st and 2nd semester. Fine mode VARIMAX rotated factor-loading matrices are shown in Table 2, while in Table 3 the results for the coarse mode are shown. It is also possible to observe in these tables the component and cumulative explained variance, and the communalities for each element included in the analysis.

In the 1st semester, the first factor in the fine mode (shown in Table 2) have high loadings for $\mathrm{Al}, \mathrm{Fe}, \mathrm{Si}, \mathrm{Ca}, \mathrm{FPM}$ and $\mathrm{K}$, representing soil dust aerosol mostly from long range transported Sahara dust. The second factor has high loadings for $\mathrm{BC}_{\mathrm{E}}, \mathrm{K}, \mathrm{S}$ and $\mathrm{FPM}$, and represents the natural biogenic aerosols. The third factor is related to P, Zn, S and FPM, and represents a second natural biogenic aerosol component. These two different components for natural biogenic aerosols were already observed in previous studies in the same area during the wet season (Artaxo and Hansson, 1995). It is normally observed that $\mathrm{K}$ and $\mathrm{P}$ have very different variability patterns, and the reason for this behavior is unknown. These 3 factors explained $91 \%$ of the data variability, with most of the communalities around $90 \%$, showing the adequacy of the 3 component factor model.

Four components were extracted for the 2 nd semester. The first $\left(\mathrm{BC}_{\mathrm{E}}, \mathrm{K}, \mathrm{FPM}\right.$ and $\left.\mathrm{S}\right)$ is related to the large scale transport of biomass burning plumes, as discussed in previous sections. The second and third factors are the soil dust and natural biogenic aerosols already also observed in the first semester. The additional fourth component is associated with the transport of seasalt aerosols $(\mathrm{Cl}$ was not included in the fine mode wet season analysis due to insufficient number of samples above detection limit). This 4 -factors solution explained $90 \%$ of the data variability in the second semester.

Factor analysis results for the coarse mode are shown in Table 3. Soil dust and biogenic components were also observed in both semesters, with a similar signature to the observed in the fine mode. The 3rd component observed for the 1 st semester, associated with $\mathrm{Cl}$, is the seasalt transport. In the 2nd semester a 4th component with absorbing aerosol $\left(\mathrm{BC}_{\mathrm{E}}\right)$ was identified. No influence of biomass burning was observed in the coarse mode, in spite of the observation of this 4th coarse mode absorbing component that we do not consider as evidence of biomass burning but natural biogenic absorbing aerosols, as pointed out in the previous section.

For the coarse mode aerosols, it is possible that the 3rd component observed during the wet season was separated in the 3rd and 4th component of the dry period. In fact, one can see that $\mathrm{BC}_{\mathrm{E}}$ loadings were 0.68 and 0.48 for the $1 \mathrm{st}$ semester analysis, in comparison to the 0.94 loading of the $\mathrm{BC}_{\mathrm{E}}$ component in the 2nd semester. It means that the 3 extracted components for the wet season were not really sufficient to explain $\mathrm{BC}_{\mathrm{E}}$ variance satisfactorily. In fact, the lowest communality observed among all analyzed elements was for $\mathrm{BC}_{\mathrm{E}}$. This $\mathrm{BC}_{\mathrm{E}}$ component in coarse mode is likely associated with optically active coarse mode natural biogenic particles. There is no evidence that biomass burning caused any increase in coarse mode $\mathrm{BC}_{\mathrm{E}}$ and no seasonal difference was observed in the concentration pattern, and instead coarse mode biogenic aerosols provide an alternative explanation. 
Table 1. First and second semester mean aerosol elemental composition in fine and coarse mode in Balbina, Central Amazonia.

\begin{tabular}{|c|c|c|c|c|}
\hline & \multicolumn{2}{|c|}{ Coarse mode } & \multicolumn{2}{|c|}{ Fine Mode } \\
\hline & 1st semester & 2nd semester & 1st semester & 2nd semester \\
\hline $\mathrm{PM}^{*}$ & $6600 \pm 2900(163)$ & $7200 \pm 2100(142)$ & $2200 \pm 1300(154)$ & $6200 \pm 3100(148)$ \\
\hline $\mathrm{BC}_{\mathrm{E}}$ & $53 \pm 16(163)$ & $48 \pm 19(142)$ & $161 \pm 129(154)$ & $490 \pm 260(148)$ \\
\hline $\mathrm{Mg}$ & $24 \pm 16(105)$ & $32 \pm 19(114)$ & $20 \pm 20(81)$ & $25 \pm 14(64)$ \\
\hline $\mathrm{Al}$ & $48 \pm 71(163)$ & $55 \pm 50(142)$ & $61 \pm 84(154)$ & $32 \pm 32(148)$ \\
\hline $\mathrm{Si}$ & $110 \pm 170(163)$ & $88 \pm 82(142)$ & $130 \pm 190(154)$ & $58 \pm 72(148)$ \\
\hline $\mathrm{P}$ & $35 \pm 11(163)$ & $25 \pm 13(142)$ & $4.2 \pm 2.2(154)$ & $6 \pm 3(148)$ \\
\hline S & $37 \pm 17(163)$ & $54 \pm 22(142)$ & $100 \pm 63(154)$ & $310 \pm 180(148)$ \\
\hline $\mathrm{Cl}$ & $73 \pm 77(163)$ & $75 \pm 73(142)$ & $10 \pm 13(103)$ & $10 \pm 8(123)$ \\
\hline K & $93 \pm 27(163)$ & $77 \pm 29(142)$ & $40 \pm 35(154)$ & $140 \pm 88(148)$ \\
\hline $\mathrm{Ca}$ & $26 \pm 28(163)$ & $26 \pm 16(142)$ & $15 \pm 17(154)$ & $13 \pm 9(148)$ \\
\hline $\mathrm{Ti}$ & $5.3 \pm 6.8(123)$ & $5.6 \pm 5.7(142)$ & $5.3 \pm 6.7(124)$ & $3.4 \pm 3.2(111)$ \\
\hline V & $0.51 \pm 0.34(5)$ & $0.80 \pm 0.63$ & $0.82 \pm 0.38$ & $1.4 \pm 0.9(5)$ \\
\hline $\mathrm{Cr}$ & $2.1 \pm 1.7(57)$ & $2.3 \pm 1.9(18)$ & $1.3 \pm 0.8(76)$ & $1.6 \pm 1.6(29)$ \\
\hline $\mathrm{Mn}$ & $1.0 \pm 0.9(130)$ & $0.85 \pm 0.61(108)$ & $0.91 \pm 0.95(100)$ & $0.59 \pm 0.49(77)$ \\
\hline $\mathrm{Fe}$ & $34 \pm 50(163)$ & $40 \pm 30(142)$ & $36 \pm 50(154)$ & $20 \pm 19(148)$ \\
\hline $\mathrm{Ni}$ & $0.38 \pm 0.55$ & $0.33 \pm 0.36(20)$ & $0.77 \pm 0.74(101)$ & $1.1 \pm 1.0(31)$ \\
\hline $\mathrm{Cu}$ & $0.34 \pm 0.49(103)$ & $0.30 \pm 0.32(72)$ & $0.55 \pm 0.60(113)$ & $0.44 \pm 0.53(75)$ \\
\hline $\mathrm{Zn}$ & $0.95 \pm 0.42(163)$ & $0.92 \pm 0.48(142)$ & $0.70 \pm 0.63(154)$ & $1.5 \pm 1.1(148)$ \\
\hline $\mathrm{Br}$ & $0.39 \pm 0.28(17)$ & $0.38 \pm 0.12(11)$ & $2.7 \pm 1.6(73)$ & $2.5 \pm 2.4(98)$ \\
\hline $\mathrm{Pb}$ & $0.19 \pm 0.12(14)$ & $0.30 \pm 0.13(18)$ & $0.24 \pm 0.16(24)$ & $0.36 \pm 0.20(60)$ \\
\hline
\end{tabular}

All values are expressed in $\mathrm{ng} \mathrm{m}^{-3}$ and the variability represents standard deviation of measurements. The number between brackets represents the number of samples that presented concentrations above the detection limit.

*PM is the Particulate Matter concentration

Table 2. Component loadings from the application of Principal Component Analysis for fine mode aerosol concentration data*. Results are shown separately for the 1st and 2nd semester. In the last line, it is shown the explained and cumulative (between brackets) variance for each extracted component. Chlorine was not included in the wet season analysis due to insufficient samples above detection limits to perform component analysis.

\begin{tabular}{|c|c|c|c|c|c|c|c|c|c|}
\hline & \multicolumn{4}{|c|}{1 st semester } & \multicolumn{5}{|c|}{ 2nd semester } \\
\hline & $\begin{array}{r}\text { Saharan } \\
\text { absorbing }\end{array}$ & $\begin{array}{r}\text { Biogenic } \\
\text { dust }\end{array}$ & $\begin{array}{r}\text { Biogenic } \\
\text { non absorbing }\end{array}$ & $\begin{array}{c}\mathrm{COM}^{\mathrm{b}} \\
\text { Burning }\end{array}$ & $\begin{array}{r}\text { Biomass } \\
\text { dust }\end{array}$ & $\begin{array}{r}\text { Saharan } \\
\text { absorbing }\end{array}$ & Biogenic non & Seasalt & $\mathrm{COM}^{\mathrm{b}}$ \\
\hline $\mathrm{BC}_{\mathrm{E}}$ & 0.31 & 0.92 & - & 0.95 & 0.94 & - & - & - & 0.93 \\
\hline $\mathrm{K}$ & 0.64 & 0.71 & - & 0.94 & 0.91 & - & - & - & 0.97 \\
\hline $\mathrm{FPM}^{a}$ & 0.66 & 0.56 & 0.37 & 0.89 & 0.91 & - & 0.32 & - & 0.94 \\
\hline $\mathrm{S}$ & - & 0.71 & 0.54 & 0.88 & 0.74 & - & 0.36 & 0.41 & 0.85 \\
\hline $\mathrm{Al}$ & 0.95 & - & - & 0.99 & - & 0.98 & - & - & 0.97 \\
\hline $\mathrm{Fe}$ & 0.95 & - & - & 0.99 & - & 0.97 & - & - & 0.96 \\
\hline $\mathrm{Si}$ & 0.96 & - & - & 0.99 & - & 0.97 & - & - & 0.95 \\
\hline $\mathrm{Ca}$ & 0.89 & 0.30 & - & 0.90 & 0.36 & 0.78 & - & 0.34 & 0.85 \\
\hline $\mathrm{Zn}$ & - & 0.38 & 0.71 & 0.70 & 0.39 & - & 0.80 & - & 0.83 \\
\hline $\mathrm{P}$ & - & - & 0.95 & 0.91 & 0.40 & - & 0.64 & 0.40 & 0.74 \\
\hline $\mathrm{Cl}$ & - & - & - & - & - & - & - & 0.90 & 0.94 \\
\hline $\begin{array}{l}\text { Cumulative } \\
\text { Variance }(\%)\end{array}$ & 46 & $26(72)$ & $19(91)$ & & 33 & $32(65)$ & $13(78)$ & $12(90)$ & \\
\hline
\end{tabular}

*Loadings smaller than 0.20 were omitted.

${ }^{\mathrm{a}} \mathrm{FPM}$ is Fine Particulate Mass concentration

${ }^{\mathrm{b}} \mathrm{COM}$ is the communality correspondent to the chemical compound 

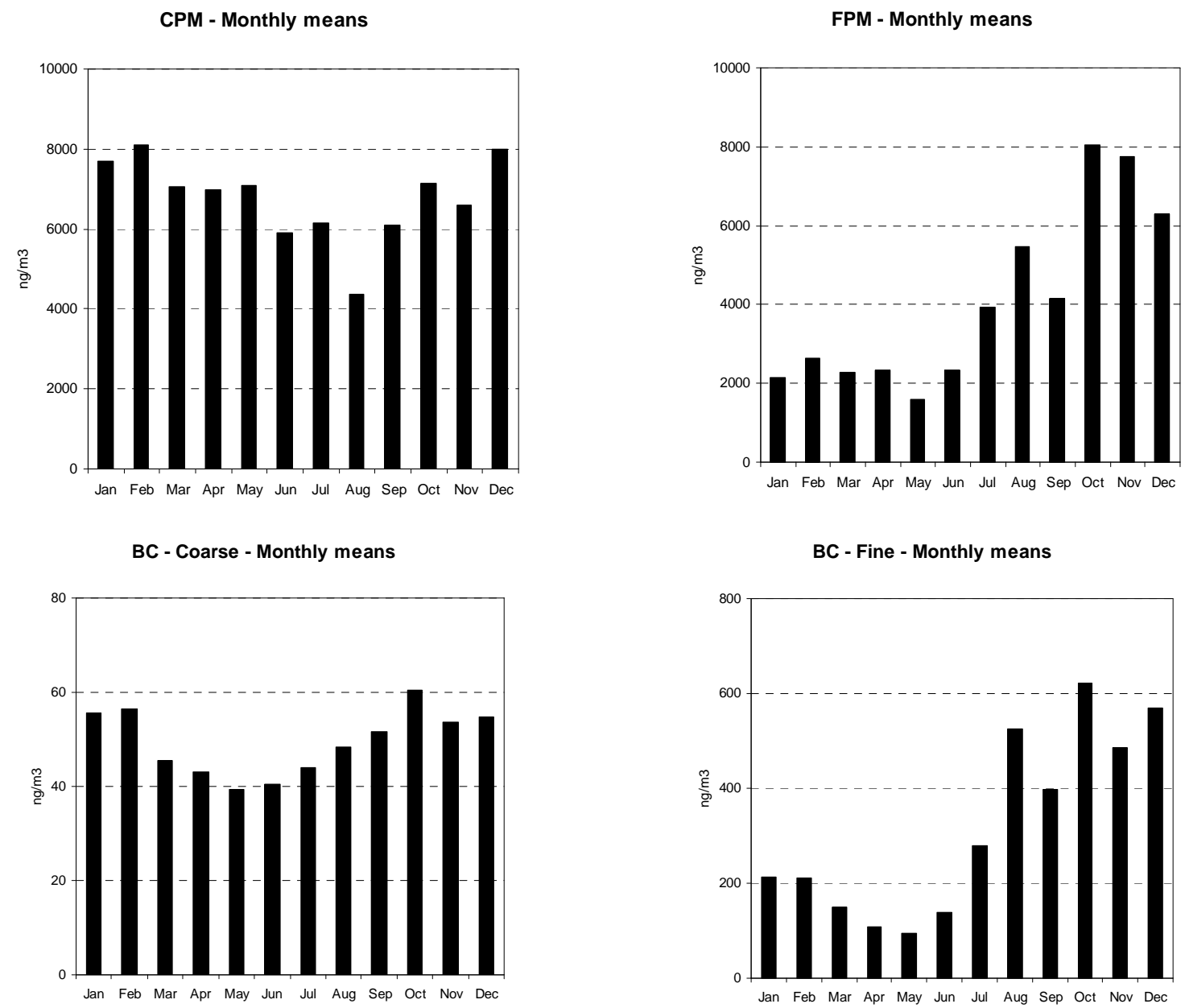

K - Coarse - Monthly means

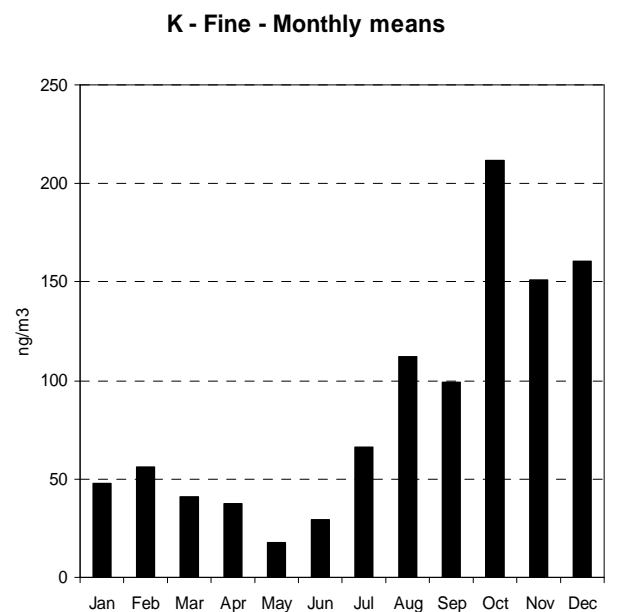

Fig. 6. Monthly means of coarse mode (left) and fine (right) particulate, black carbon equivalent and elemental mass concentration. 

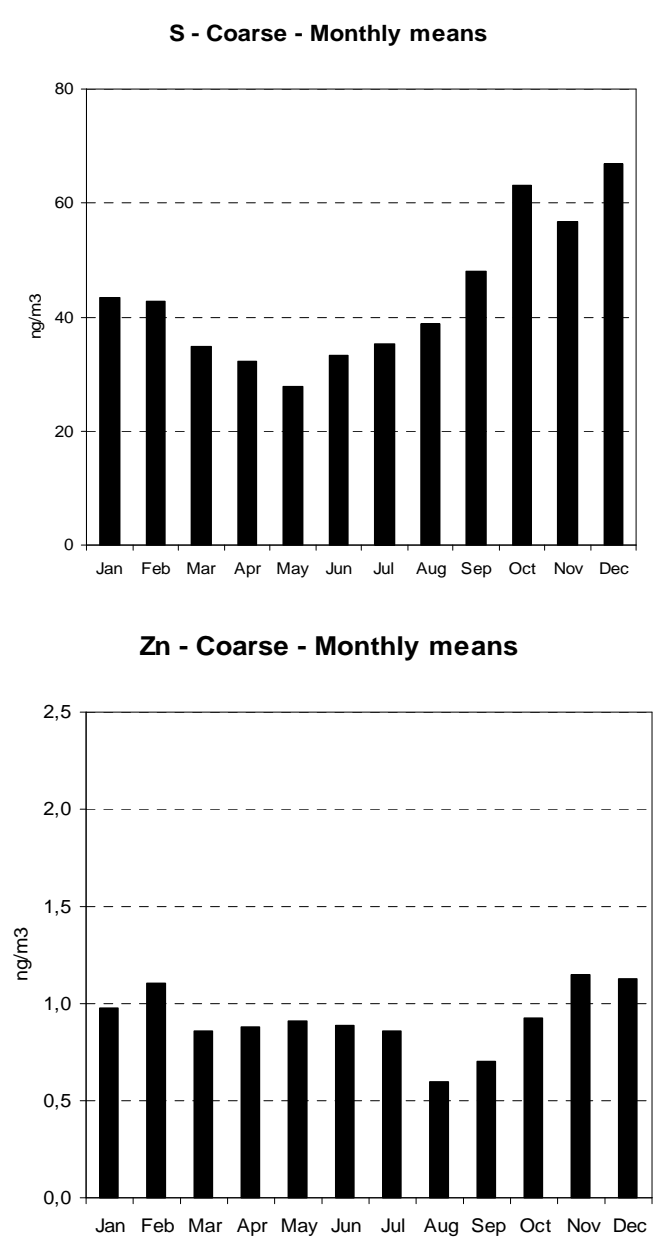

$\mathrm{Cl}$ - Coarse - Monthly means

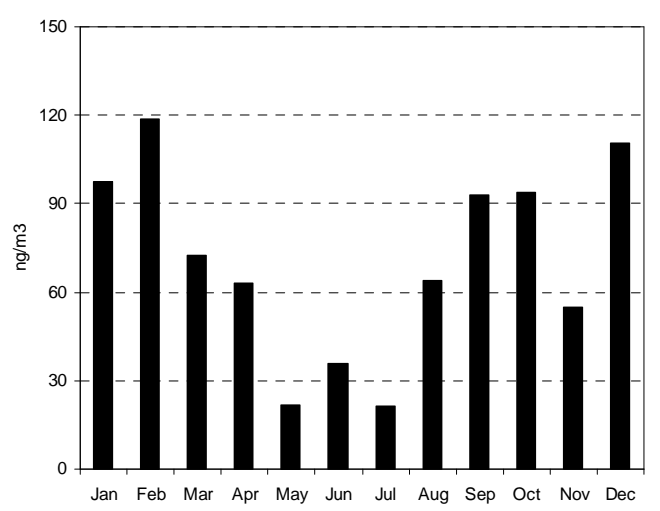

Fig. 6. Continued.

In fact, when we visually inspect the coarse mode filters after 3-4 days collection in the wet season, they are actually gray in color. On the other hand, fine mode $\mathrm{BC}_{\mathrm{E}}$ is clearly associated with biomass burning emissions during the dry season, given the clear seasonality of measurements, with
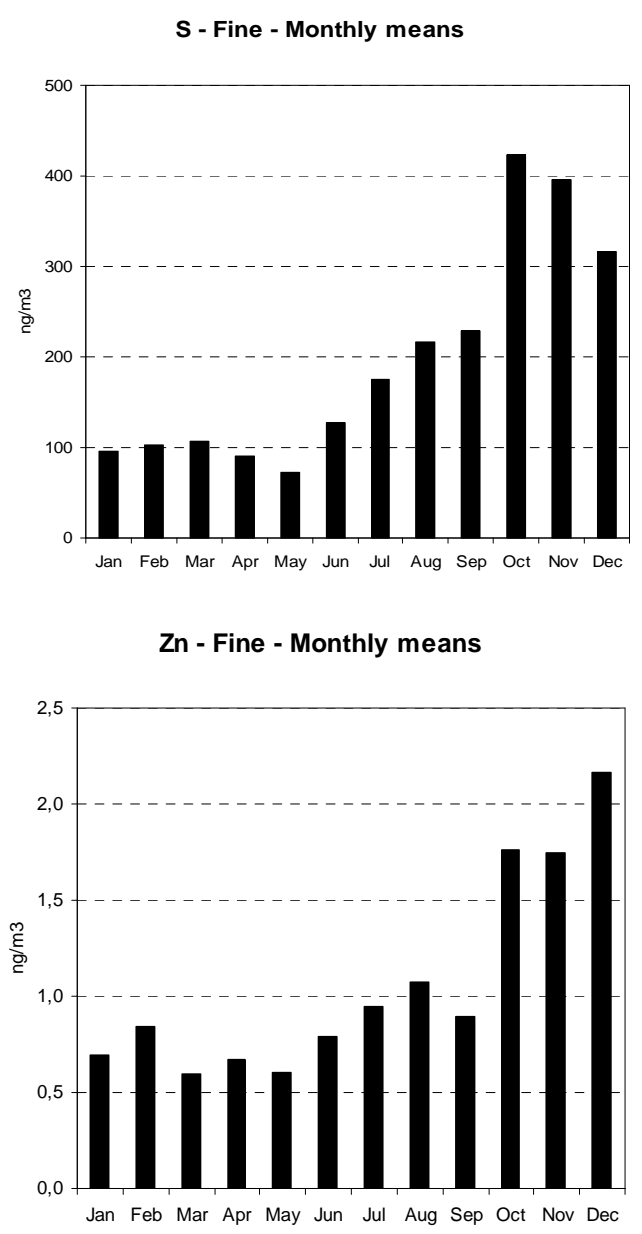

Cl - Fine - Monthly means

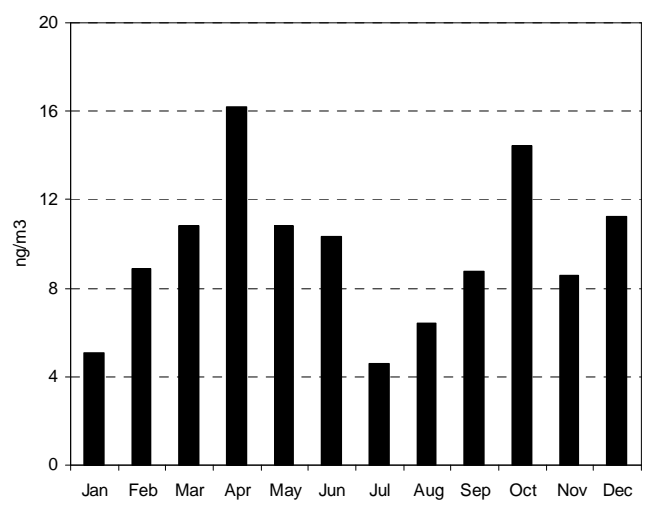

a somewhat constant component due to absorption by fine mode biogenic aerosol, often called "brown carbon", during the wet season.

The absolute apportionment of trace element concentrations was obtained through the application of the APFA 


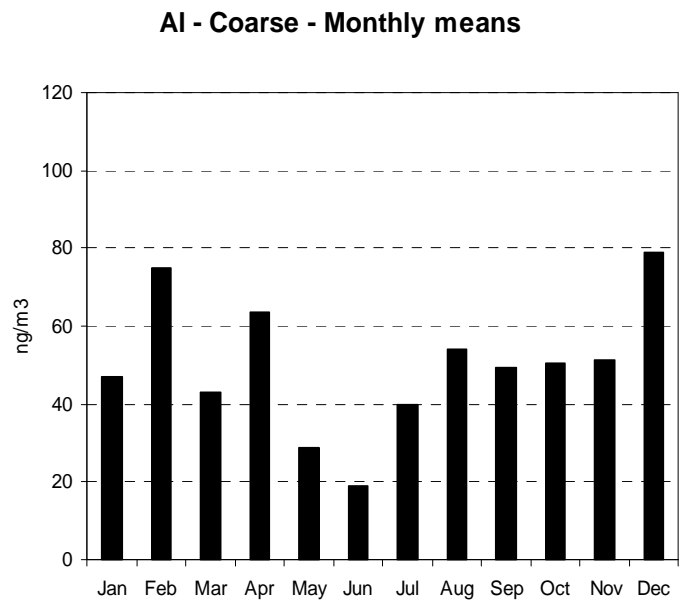

Si - Coarse - Monthly means

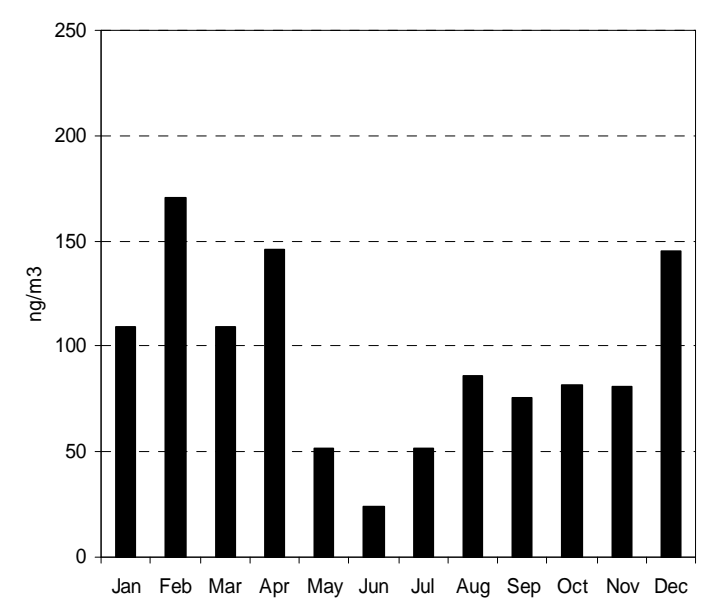

$\mathrm{Fe}$ - Coarse - Monthly means

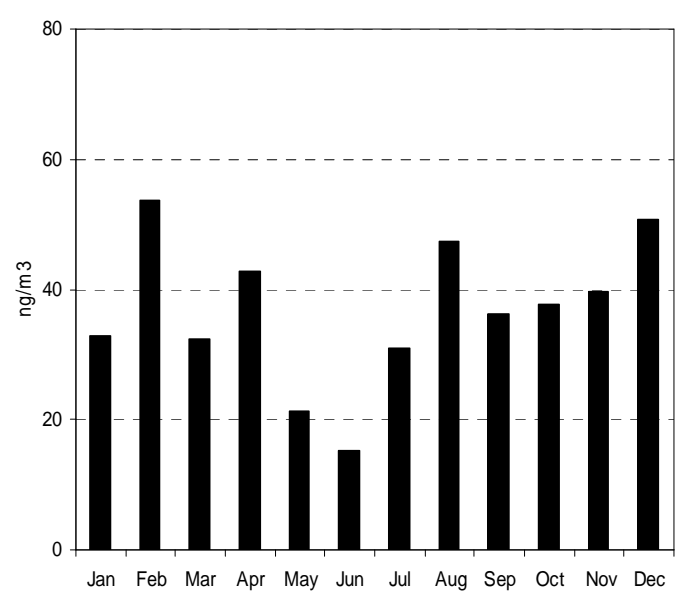

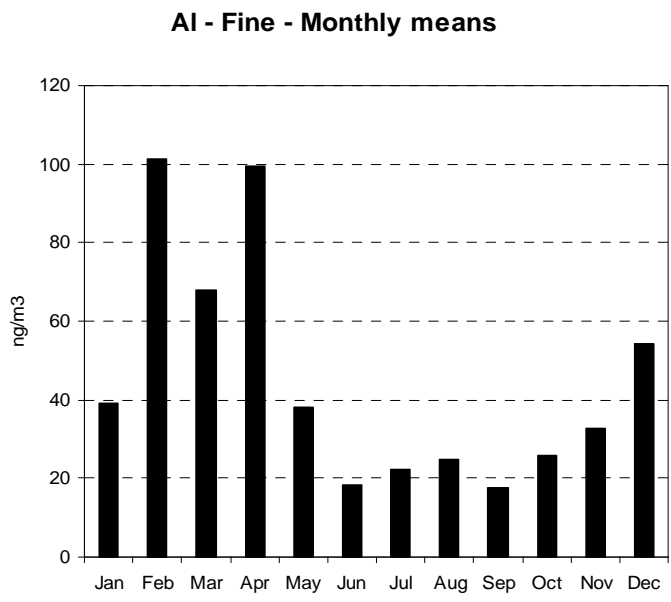

Si - Fine - Monthly means

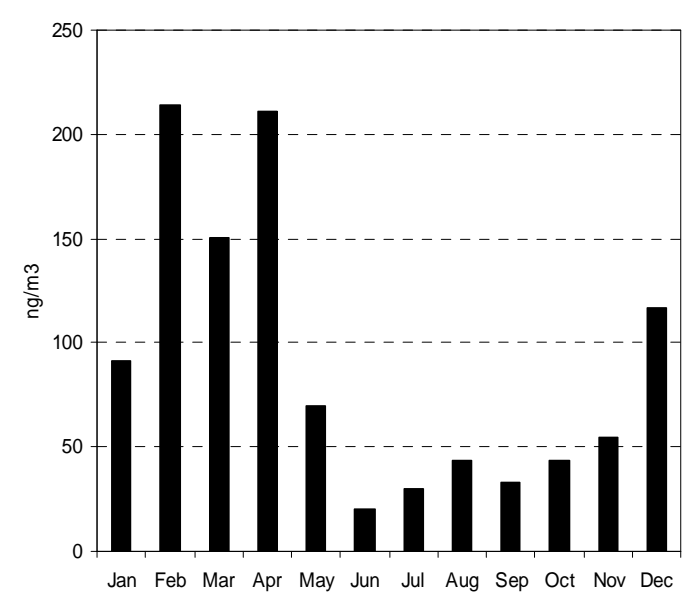

Fe - Fine - Monthly means

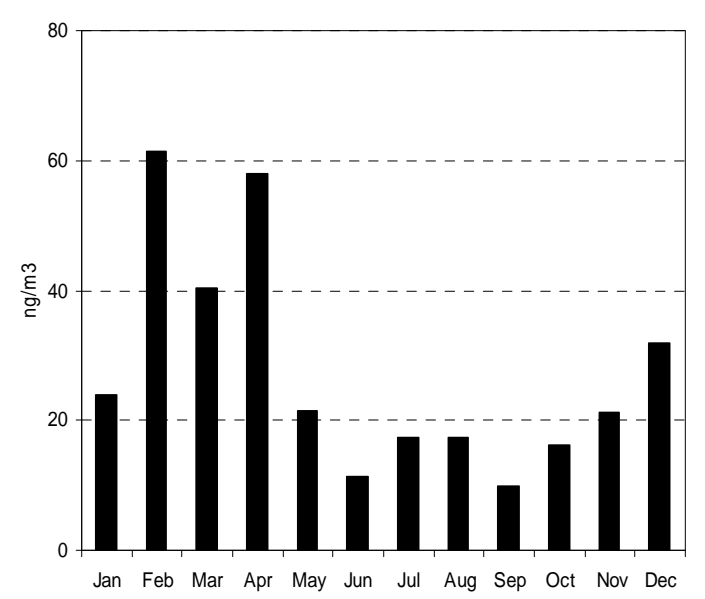

Fig. 6. Continued. 
Ti - Coarse - Monthly means

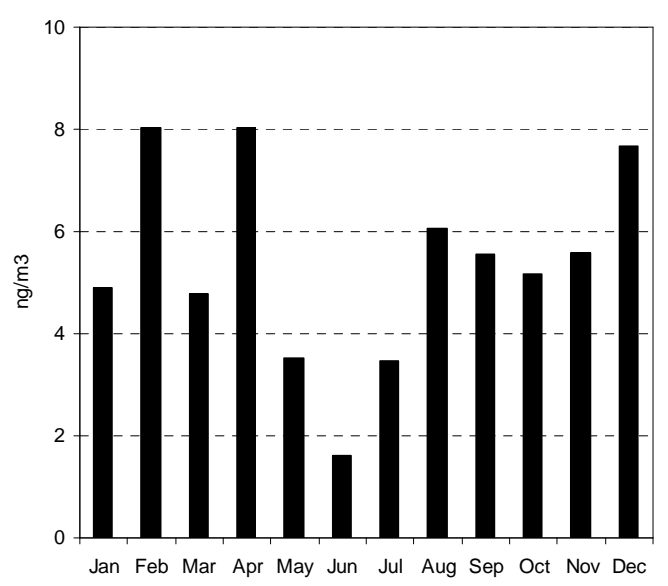

Ca - Coarse - Monthly means

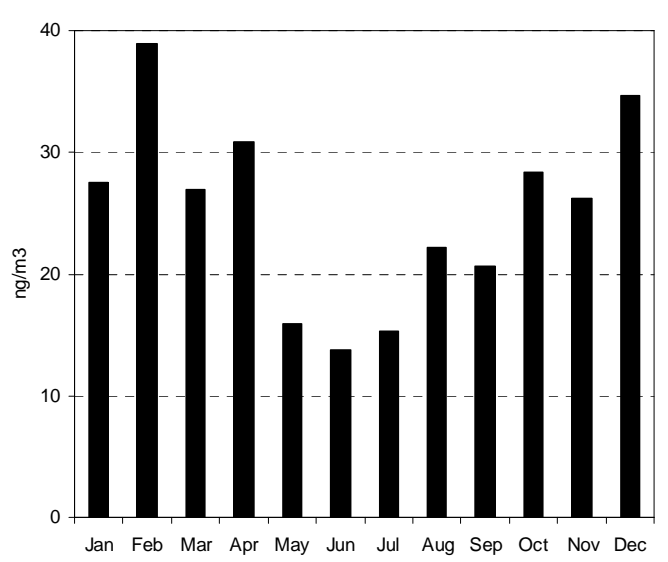

Ti - Fine - Monthly means

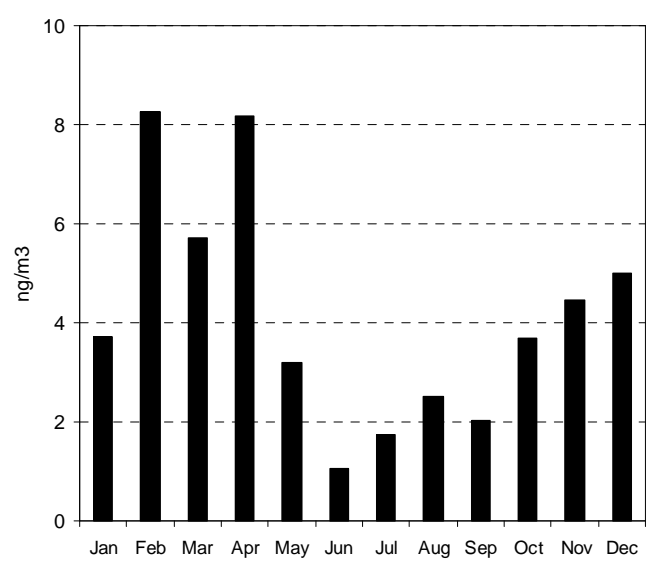

Ca - Fine - Monthly means

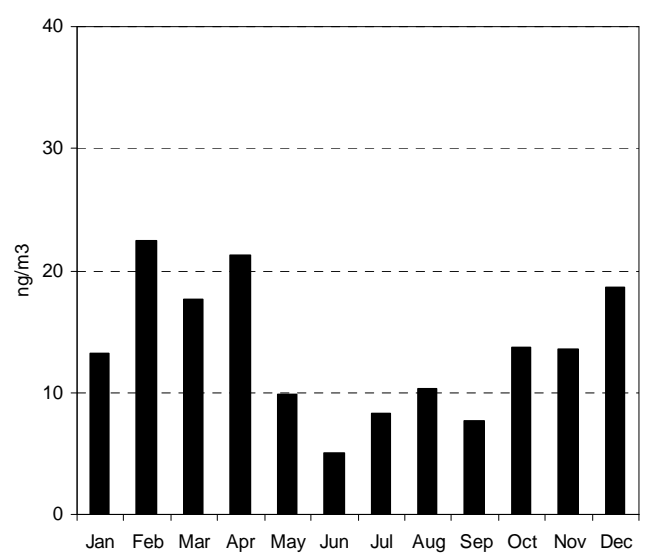

Fig. 6. Continued.

procedure. The mean 1 st and 2 nd semester results are presented in Figs. 9 and 10, respectively. In the 1st semester natural biogenic particles dominate the aerosol mass, with $90 \%$ of the coarse mode and $83 \%$ of the fine mode aerosol, followed by soil dust with $5 \%$ and $17 \%$ of coarse and fine modes, respectively. The small contribution of soil dust in the coarse mode is due to the combination of the soil being covered permanently with a thick forest litter and very high humidity, which suppresses the emission of dust particles.

With respect to the 2nd semester APFA analysis (Fig. 10), the non absorbing biogenic aerosol contribution was also predominant in the coarse mode ( $83 \%$ of the aerosol mass), followed by soil dust (7\%), absorbing biogenic aerosols (5\%) and seasalt $(5 \%)$. In the fine mode, biomass burning contribution dominates the picture with $77 \%$ of fine aerosol mass, followed by biogenic aerosols (13\%), soil dust (6\%) and seasalt $(4 \%)$

In Figs. 11 and 12 these results are shown as time series throughout the entire sampled period. The biogenic contribu- tion is displayed in Figs. 11a (fine mode) and 12a (coarse). The absorbing and non-absorbing components are shown separately. In fine mode they have the same order of magnitude, while in the coarse mode the non-absorbing component domains the picture, with concentration 20 times greater than the absorbing component whose average concentration of $300 \mathrm{ng} \mathrm{m}^{-3}$ represents approximately $5 \%$ of the CPM.

Surprisingly, a decrease in the concentration of the nonabsorbing biogenic component was observed both in fine and coarse modes. This result is unexpected. The rainforest environment surrounding the site area has been well preserved during the sampling period, and no significant changes (e.g. deforestation) have taken place within hundreds of kilometers from the sampling area. We could not provide any plausible explanation for the behavior of this biogenic component.

Soil dust time series in fine and coarse modes is shown in Figs. $11 \mathrm{~b}$ and $12 \mathrm{~b}$. It is possible to observe that the typical behavior of this component is a rather small background concentration with extreme peaks. A possible explanation 
for this behavior is the occurrence of burst events related to weather changes (e.g. squall lines) that favor the transport of soil dust originated from Sahara, especially in April and May when the Amazon Basin is subject to large-scale transport of these particles (Swap et al., 1992, 1996; Formenti et al., 2001).

Biomass-burning component (only 2nd semester data), is shown in Fig. 11c. As expected from a very seasonal source, it presents the largest amplitude among the extracted components, with concentrations up to $12000 \mathrm{ng} \mathrm{m}^{-3}$. It also presents important inter-annual differences, which are controlled by basin-wide climatological issues.

In Fig. 12c the contribution of coarse mode seasalt can be observed. It also had important inter-annual variability, since year to year precipitation patterns vary significantly as well as the long range transport from the tropical Atlantic Ocean to Amazonia.

\subsection{Rainwater chemistry measurements}

\subsubsection{Comparison of rainwater chemistry in Central Amazonia to other remote sites around the world}

The annual VWM concentrations are compared to results from other remote sites around the world in Table 4. The observed ionic concentrations were similar to the observed in other tropical remote regions around the world, when little biomass burning impact is observed. The mean observed acidity was $<\mathrm{pH}>=4.90$, within the range 4.4-5.5. This $\mathrm{pH}$ value is in agreement with typical acidity observed in the other remote sites except for the African Savanna site. The explanation for the discrepancy is the high buffering capacity for this site, as one can see by its higher concentration of $\mathrm{NH}_{4}^{+}$and $\mathrm{Ca}^{2+}$ in the Sahelian savanna site than observed in other measurements.

Buffering capacity in our site was low compared to other remote sites. VWM for $\mathrm{NH}_{4}^{+}$was similar to the observed in the previous work conducted in central Amazonia by Williams et al. (1997). Furthermore, $\mathrm{NH}_{4}^{+}$was remarkably lower than the observed concentration in Zoétélé (SighaNkandjou et al., 2003), a similar ecosystem site in the African rainforest, and for the South African semi-arid site (Mphepya et al., 2004). The authors reported that this enhanced concentration of $\mathrm{NH}_{4}^{+}$(and also of $\mathrm{K}^{+}$and $\mathrm{Cl}^{-}$) in African sites was due to the influence of biomass burning during the dry season, which is not the case for Balbina. For the Sahelian Savanna site (Galy-Lacaux and Modi, 1998), the authors attributed the origin of the levels of $\mathrm{NH}_{4}^{+}$in rainwater to the high density of domestic animals in the region and its related production of ammonia, as a result of hydrolysis of urea deposited in pasture-grazing areas. This is also an absent influence in Central Amazonia.

A remarkable difference between Balbina and the other remote sites was the smaller concentration of formate in comparison with acetate, which are anions directly associated with the presence of formic and acetic acids. This is an unexpected result because in remote areas of the world the most typical result is a predominance of formic $(\mathrm{F})$ over acetic (A) acid (Keene et al., 1983; Sanhueza et al., 1991, 1992; Chebbi and Carlier, 1996). The observed mean F:A ratio in this work was 0.23. Williams et al. (1997) in a site relatively near our measurement site also observed this predominance of acetate over formate in Central Amazonia $(F: A=0.31)$, which indicates that our result is not an artifact or due to analytical issues. However, we could not provide any explanation for this divergent result from other remote places. Andreae et al. (1990) collected rain samples during a short period during the wet season ( 6 weeks) and obtained $F: A=1.5$, but in this study it was not possible to observe such result even for the similar period in the year.

VWM for $\mathrm{Na}^{+}$was lower than the reported values of other sites subject to marine influence (e.g. Costa Rica $\mathrm{VWM}_{\mathrm{Na}^{+}}=27.2 \mu \mathrm{eq} 1^{-1}$ ) (Elklund et al., 1997). However, it was not so small if one has in mind that Balbina is about $1200 \mathrm{~km}$ from the Atlantic coastline. For comparison, the Zoétélé site is relatively close to the coastline (about $200 \mathrm{~km}$ ) and presented a similar $\mathrm{Na}^{+}$VWM concentration of $4.0 \mu \mathrm{eq}^{-1}$ (Sigha-Nkandjou et al., 2003). This could be due to the presence of a mountain range between Zoétélé and the coastline, which is an important local driver for the generation of orographic rains for air masses coming from the ocean. Thus, most of $\mathrm{Na}^{+}$is scavenged before it can reach Zoétélé. In Central Amazonia, the very large precipitation rate and efficient removal of possible sea-salt component along the $1200 \mathrm{~km}$ distance from the Atlantic is responsible for the observed $\mathrm{Na}^{+}$concentrations. Considering that the altitude difference between Manaus and its estuary is about $80 \mathrm{~m}$, it is reasonable that, under adequate weather conditions, oceanic air masses could be advected to Central Amazonia and carry with them sea-salt aerosols that would be gradually scavenged by wet deposition along its path.

\subsubsection{Analysis of Balbina rainwater chemistry measurements}

VWM concentrations and wet deposition rates are shown in Table 5. As for aerosols, averages are shown as annual, 1st and 2nd semester means and subject to the same bias due to the transition months, but also keeping its representativity with respect to the wet and dry seasons.

With respect to the annual mean, the most abundant ion was $\mathrm{H}^{+}$followed in decreasing order of importance by $\mathrm{NO}_{3}^{-}$, Acetate, $\mathrm{Cl}^{-}, \mathrm{Na}^{+}, \mathrm{NH}_{4}^{+}, \mathrm{SO}_{4}^{2-}, \mathrm{Mg}^{2+}, \mathrm{Ca}^{2+}, \mathrm{K}^{+}, \mathrm{F}^{-}$, Formate, Oxalate, $\mathrm{NO}_{2}^{-}, \mathrm{Br}^{-}$, Citrate and $\mathrm{PO}_{4}^{3-}$. In a general way, many ions showed a larger concentration in the 2 nd than in the 1st semester. It is the case for the major ions $\mathrm{H}^{+}$, $\mathrm{Na}^{+}, \mathrm{K}^{+}, \mathrm{Mg}^{2+}, \mathrm{Ca}^{2+}, \mathrm{F}^{-}, \mathrm{Cl}^{-}, \mathrm{NO}_{3}^{-}, \mathrm{SO}_{4}^{2}$ - and (to a lesser extent) DIC (Dissolved Inorganic Carbon). However, it was not possible to observe pronounced differences in the corresponding deposition fluxes for most ions due to the inversely 
Table 3. The same as Table 2, but for the coarse mode aerosols*. Ti in the 1st semester was not included due to insufficient samples above detection limits to perform component analysis.

\begin{tabular}{|c|c|c|c|c|c|c|c|c|c|}
\hline & \multicolumn{4}{|c|}{ 1st semester } & \multicolumn{4}{|c|}{ 2nd semester } & \multirow[b]{2}{*}{$\mathrm{COM}^{\mathrm{b}}$} \\
\hline & $\begin{array}{l}\text { Saharan } \\
\text { dust }\end{array}$ & $\begin{array}{l}\text { Biogenic } \\
\text { (total) }\end{array}$ & $\begin{array}{l}\text { Sea salt } \\
\text { salt }\end{array}$ & $\mathrm{COM}^{\mathrm{b}}$ & $\begin{array}{l}\text { Saharan } \\
\text { dust }\end{array}$ & $\begin{array}{l}\text { Biogenic } \\
\text { non absorbing }\end{array}$ & Sea & $\begin{array}{l}\text { Biogenic } \\
\text { absorbing }\end{array}$ & \\
\hline $\mathrm{Si}$ & 0.95 & - & - & 0.99 & 0.90 & - & 0.39 & - & 0.97 \\
\hline $\mathrm{Al}$ & 0.94 & - & - & 0.98 & 0.96 & - & - & - & 0.98 \\
\hline $\mathrm{Fe}$ & 0.94 & - & - & 0.99 & 0.95 & - & - & - & 0.96 \\
\hline $\mathrm{Ti}$ & & & & & 0.97 & - & - & - & 0.96 \\
\hline $\mathrm{Ca}$ & 0.86 & - & 0.39 & 0.92 & 0.52 & - & 0.72 & - & 0.85 \\
\hline $\mathrm{P}$ & - & 0.94 & - & 0.94 & - & 0.95 & - & - & 0.96 \\
\hline $\mathrm{Zn}$ & - & 0.86 & - & 0.79 & - & 0.78 & - & - & 0.72 \\
\hline $\mathrm{K}$ & 0.43 & 0.86 & - & 0.94 & - & 0.93 & - & - & 0.92 \\
\hline $\mathrm{CPM}^{\mathrm{a}}$ & 0.44 & 0.81 & - & 0.92 & - & 0.89 & - & - & 0.89 \\
\hline $\mathrm{BC}_{\mathrm{E}}$ & 0.37 & 0.68 & 0.48 & 0.81 & - & - & - & 0.94 & 0.95 \\
\hline S & 0.47 & 0.61 & 0.58 & 0.91 & - & 0.49 & 0.62 & 0.41 & 0.87 \\
\hline $\mathrm{Cl}$ & 0.54 & - & 0.80 & 0.92 & - & - & 0.92 & - & 0.92 \\
\hline $\begin{array}{l}\text { Cumulative } \\
\text { Variance }(\%)\end{array}$ & 40 & $35(75)$ & $17(92)$ & & 35 & $29(64)$ & $17(81)$ & $10(91)$ & \\
\hline
\end{tabular}

Table 4. Comparison of the rainwater chemistry results obtained in this study with other data from remote sites around the world. Values represent annual Volume Weighted Means expressed in $\mu$ eq $1^{-1}$, except for DIC expressed in $\mu \mathrm{m}^{-1}$.

\begin{tabular}{|c|c|c|c|c|c|c|c|c|c|c|}
\hline & $\begin{array}{r}\text { This } \\
\text { work }\end{array}$ & $\begin{array}{r}\text { Africa } \\
\text { Sahelian } \\
\text { Savanna }^{1}\end{array}$ & $\begin{array}{r}\text { Africa } \\
\text { Forest } \\
(\text { Zoetele })^{2}\end{array}$ & $\begin{array}{r}\text { South } \\
\text { Africa } \\
\text { Semi arid }^{3}\end{array}$ & $\begin{array}{r}\text { Torres del } \\
\text { Paine }\end{array}$ & $\begin{array}{r}\text { Venezuela } \\
(\text { Savanna) }\end{array}$ & Austrália $^{6}$ & $\begin{array}{l}\text { Costa } \\
\text { Rica }^{7}\end{array}$ & Amazonia $^{8}$ & $\begin{array}{r}\text { Amazonia } \\
\text { (wet season) }\end{array}$ \\
\hline $\mathrm{pH}$ & 4.90 & 5.7 & & & & $4.6-5.4$ & & & 4.77 & \\
\hline $\mathrm{H}^{+}$ & 12.6 & 2.1 & 12.0 & 12.2 & 10.9 & $4.3-23.6$ & 16.3 & 4.6 & 17 & 5.6 \\
\hline $\mathrm{Na}^{+}$ & 3.8 & 7.7 & 4.0 & 9.3 & 13.2 & $3.5-8.1$ & 3.3 & 27.2 & 2.4 & 3.5 \\
\hline $\mathrm{NH}_{4}^{+}$ & 3.7 & 12.9 & 10.5 & 9.7 & 0.6 & $<1.9-13.4$ & 2.8 & 6.0 & 3.0 & 1.9 \\
\hline $\mathrm{K}^{+{ }^{4}}$ & 1.5 & 4.7 & 5.0 & 3.8 & 0.4 & $0.26-7.2$ & 0.8 & 1.8 & 0.8 & 1.6 \\
\hline nss-K ${ }^{+}$ & 1.39 & & & & & $0.23-7.1$ & & 1.2 & 0.75 & \\
\hline $\mathrm{Mg}^{2+}$ & 1.93 & 5.6 & 2.4 & 4.1 & 3.2 & $0.48-4.0$ & 1.0 & 7.4 & 0.90 & 0.71 \\
\hline nss-Mg ${ }^{2+}$ & 1.06 & & & & & $0.11-2.2$ & & 1.3 & 0.36 & \\
\hline $\mathrm{Ca}^{2+}$ & 1.81 & 31.2 & 8.9 & 12.0 & 1.1 & $0.94-14.6$ & 1.5 & 6.8 & 2.40 & 1.2 \\
\hline nss-Ca ${ }^{2+}$ & 1.64 & & & & & $0.88-14.2$ & & 5.6 & 2.29 & \\
\hline $\mathrm{F}^{-}$ & 0.76 & & & & & & & & & \\
\hline Acetate & 5.2 & 2.7 & 3.2 & 4.3 & 0.5 & $2.1-5.9$ & 2.1 & & 9.3 & 2.3 \\
\hline Formate & 0.45 & 4.5 & 8.2 & 11.5 & 4.9 & $5.9-8.4$ & 9.6 & & 2.9 & 3.2 \\
\hline $\mathrm{Cl}^{-}$ & 5.2 & 7.4 & 4.3 & 10.0 & 17.0 & $3.5-11.8$ & 6.1 & 33.0 & 4.6 & 3.9 \\
\hline nss- $\mathrm{Cl}^{-}$ & 0.7 & & & & & $1.9-4.1$ & & 1.5 & 1.8 & \\
\hline $\mathrm{NO}_{2}^{-}$ & 0.054 & & & & & & & & & \\
\hline $\mathrm{Br}^{-}$ & 0.029 & & & & & & & & & \\
\hline $\mathrm{NO}_{3}^{-}$ & 5.4 & 12.3 & 6.9 & 8.0 & 0.5 & $2.3-4.6$ & 3.6 & 4.1 & 4.2 & 1.09 \\
\hline $\mathrm{SO}_{4}^{2-}$ & 3.4 & 8.6 & 5.1 & 14.5 & 2.8 & $2.7-5.6$ & 3.0 & 14.8 & 2.00 & 0.9 \\
\hline nss-SO ${ }_{4}^{2-}$ & 3.0 & & & & & $2.1-4.6$ & & 11.5 & 1.71 & \\
\hline Oxalate & 0.25 & 1.0 & & & & & & & & 0.13 \\
\hline $\mathrm{PO}_{4}^{3-}$ & 0.0085 & & & & 0.06 & & & & 0.03 & \\
\hline Citrate & 0.022 & & & & & & & & & \\
\hline $\mathrm{DIC}^{\mathrm{a}}$ & 23.4 & & & & & & & & & \\
\hline $\mathrm{DEF}^{\mathrm{b}}$ & 5.5 & & & & & & & & & \\
\hline
\end{tabular}

References: ${ }^{1}$ Galy-Lacaux and Modi (1998); ${ }^{2}$ Sigha-Nkamdjou et al. (2003); ${ }^{3}$ Mphepya et al. (2004); ${ }^{4}$ Galloway et al. (1996); ${ }^{5}$ Sanhueza et al. (1992); ${ }^{6}$ Likens et al (1987); ${ }^{7}$ Elklund et al. (1997); ${ }^{8}$ Williams et al. (1997); ${ }^{9}$ Andreae et al. (1990).

${ }^{a}$ DIC is Dissolved Inorganic Carbon, which is expressed in $\mu \mathrm{m}^{-1}$

${ }^{\mathrm{b}} \mathrm{DEF}$ is ionic deficit, defined as ( $\Sigma$ cations- $\Sigma$ anions) and expressed in $\mu$ eq $1^{-1}$. 
Table 5. Volume Weighted Mean (VWM) concentrations and deposition rates observed in rainwater at Balbina. Results area shown separately for wet and dry seasons and annual mean. The range column refers to minimum and maximum observed concentration observed in the collected samples. Concentrations are expressed in $\mu$ eq $\mathrm{l}^{-1}$ (except for DIC expressed in $\mu \mathrm{ml}^{-1}$ ), and deposition rates in $\mu$ eq $\mathrm{m}^{-2}\left(\mu \mathrm{M} \mathrm{m}{ }^{-2}\right.$ ).

\begin{tabular}{|c|c|c|c|c|c|c|c|}
\hline & \multicolumn{4}{|c|}{ Concentration } & \multicolumn{3}{|c|}{ Deposition } \\
\hline & Wet & Dry & Annual & Range & Wet & Dry & Annual \\
\hline $\mathrm{pH}$ & 5.01 & 4.80 & 4.90 & $4.4-5.5$ & & & \\
\hline $\mathrm{H}^{+}$ & 9.7 & 16.0 & 12.6 & $1.7-38$ & 17.2 & 14.0 & 33.4 \\
\hline $\mathrm{Na}^{+}$ & 2.4 & 5.6 & 3.8 & $0.62-25$ & 4.3 & 4.9 & 10.1 \\
\hline $\mathrm{NH}_{4}^{+}$ & 3.4 & 3.9 & 3.7 & $0.27-19$ & 6.0 & 3.4 & 9.8 \\
\hline $\mathrm{K}^{+}$ & 1.1 & 1.9 & 1.5 & $0.033-21$ & 2.0 & 1.7 & 4.0 \\
\hline nss-K ${ }^{+}$ & 1.1 & 1.8 & 1.4 & & 1.9 & 1.6 & 3.7 \\
\hline $\mathrm{Mg}^{2+}$ & 1.5 & 2.5 & 1.9 & $0.70-14$ & 2.6 & 2.1 & 5.1 \\
\hline nss-Mg ${ }^{2+}$ & 0.95 & 1.20 & 1.1 & & 1.7 & 1.0 & 2.8 \\
\hline $\mathrm{Ca}^{2+}$ & 1.6 & 2.1 & 1.8 & $0.30-20$ & 2.8 & 1.8 & 4.8 \\
\hline $\mathrm{nss}-\mathrm{Ca}^{2+}$ & 1.5 & 1.9 & 1.6 & & 2.6 & 1.6 & 4.3 \\
\hline $\mathrm{F}^{-}$ & 0.6 & 1.3 & 0.76 & $0.53-2.6$ & 1.1 & 1.1 & 2.0 \\
\hline Acetate & 5.2 & 5.2 & 5.2 & $0.086-19$ & 9.2 & 4.5 & 13.8 \\
\hline Formate & 0.51 & 0.41 & 0.45 & $0.58-4.9$ & 0.91 & 0.36 & 1.2 \\
\hline $\mathrm{Cl}^{-}$ & 3.3 & 7.4 & 5.2 & $0.70-29$ & 5.9 & 6.5 & 13.8 \\
\hline nss- $\mathrm{Cl}^{-}$ & 0.5 & 0.9 & 0.7 & & 0.89 & 0.79 & 1.9 \\
\hline $\mathrm{NO}_{2}^{-}$ & 0.049 & 0.058 & 0.054 & $0.0043-1.0$ & 0.087 & 0.051 & 0.14 \\
\hline $\mathrm{Br}^{-2}$ & 0.030 & 0.025 & 0.029 & $0.0025-0.12$ & 0.053 & 0.022 & 0.077 \\
\hline $\mathrm{NO}_{3}^{-}$ & 3.7 & 7.5 & 5.4 & $0.40-26.9$ & 6.6 & 6.5 & 14.3 \\
\hline $\mathrm{SO}_{4}^{2-}$ & 2.0 & 5.1 & 3.4 & $0.40-27.4$ & 3.5 & 4.5 & 9.1 \\
\hline nss-SO ${ }_{4}^{2-}$ & 1.7 & 4.5 & 3.0 & & 3.0 & 3.9 & 7.8 \\
\hline Oxalate & 0.21 & 0.28 & 0.25 & $0.0091-0.83$ & 0.37 & 0.24 & 0.66 \\
\hline $\mathrm{PO}_{4}^{3-}$ & 0.0061 & 0.010 & 0.0085 & $0.0020-0.29$ & 0.011 & 0.009 & 0.023 \\
\hline Citrate & 0.031 & 0.016 & 0.022 & $0.0047-0.13$ & 0.055 & 0.014 & 0.058 \\
\hline DIC & 21.2 & 24.8 & 23.4 & 9.6-105 & 37.7 & 21.7 & 62.0 \\
\hline DEF & 5.4 & 5.7 & 5.5 & -24 to 35 & 9.6 & 5.0 & 14.6 \\
\hline
\end{tabular}

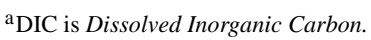

${ }^{\mathrm{b}} \mathrm{DEF}$ is ionic deficit, defined as ( $\Sigma$ cations- $\Sigma$ anions) and expressed in $\mu \mathrm{eq} \mathrm{1}^{-1}$. nss is the non-seasalt fraction

proportional rain volume. Considering that wet deposition is directly related to the loading of chemical species in the atmosphere, a possible explanation for this result is that the strength of the mechanism which releases these ions to the atmosphere is rather constant throughout the year. Further, the higher concentrations in the 2nd semester are likely connected to the less frequent removal of atmospheric particles.

The non-sea salt (nss) fraction for some selected ions is also shown in Table 5. From these results we conclude that there are other important processes than marine emissions contributing to the observed amount of $\mathrm{K}^{+}, \mathrm{Ca}^{2+}, \mathrm{SO}_{4}^{2-}$ and $\mathrm{Mg}^{2+}$ in rainwater. Indeed, the nss fraction for these ions was $86 \%$ for $\mathrm{SO}_{4}^{2-}, 93 \%$ for $\mathrm{K}^{+}, 91 \%$ for $\mathrm{Ca}^{2+}$ and $55 \%$ for $\mathrm{Mg}^{2+}$. This is in agreement with the aerosol analysis by APFA, which pointed that $\mathrm{K}, \mathrm{S}, \mathrm{Ca}$ levels are predominantly subject to the combination of biogenic, soil dust and biomass-burning sources ( $\mathrm{Mg}$ was not included in aerosol APFA). The exception to this pattern was $\mathrm{Cl}^{-}$, with a small nss fraction. It suggests the absence of any alternative process to explain $\mathrm{Cl}^{-}$in rainwater than marine emission. A linear relationship between $\mathrm{Cl}^{-}$and $\mathrm{Na}^{+}$was observed $\left(r^{2}=0.85\right.$, $p<0.01)$ indicating the presence of $\mathrm{NaCl}$ in rainwater, a result that was already reported in previous works on rainwater chemistry in Central Amazonia (Andreae et al., 1990; Williams et al., 1997) and is also in agreement with aerosol analysis of the previous section.

The concentration of oxalate was quite below the concentration of acetate and formate, which is an expected result in a remote site like Balbina. Oxalic acid is usually the most abundant among the dicarboxilic acids in the atmosphere (Kawamura et al., 1996), and in polluted circumstances (which are not our case) it can have concentration levels even higher than the sum of formic and acetic acid (Kawamura et al., 2001). The presence of oxalic acid in Balbina is likely associated to natural emissions from vegetation. Isoprene is the major volatile organic compound emitted by plants. It has been shown that pyruvic acid and methylglyoxal formed by the oxidation of isoprene act in the pathway 
of the in-cloud formation of oxalic acid (Ervens et al., 2004; Lim et al., 2005). Oxalic acid is also an end product of several photochemical oxidation reactions (Chebbi and Carlier, 1996) and can accumulate in the atmosphere. Once formed, it is expected to be quite stable and to be present as fine mode particulate. Hence, the most important removal mechanism for oxalic acid is expected to be wet deposition.

Due to the association of oxalic acid with photochemical reactions, it is believed that the hydroxyl radical $\left(\mathrm{OH}^{-}\right)$is the primary agent in the formation of oxalic acid in the atmosphere. However, the formation of $\mathrm{HNO}_{3}$ is also linked to $\mathrm{OH}^{-}$levels because it participates in the conversion mechanism of $\mathrm{NO}_{2}$ to $\mathrm{HNO}_{3}$. Thus, oxalic and nitric acid can be formed in parallel pathways, with the production rate of one well correlated with that of the other. In fact, a linear relationship was observed between oxalate and nitrate $\left(r^{2}=0.82\right.$, $p<0.01$ ), and we suggest that this similar dependence with $\mathrm{OH}^{-}$is the reason for this correlation.

\subsubsection{Monthly analysis of rainwater chemistry}

In Fig. 7 it is displayed the monthly evolution of VWM and wet deposition fluxes for most of the measured ions. Plots are separated in VWM concentrations on the left and wet deposition fluxes in the right side. As for aerosols, these plots improve the analysis of the annual cycle of the measured ions.

\section{The acidity profile}

Except for November that presented a pronounced difference compared to the other monthly means $\left(25.0 \mu \mathrm{eq} \mathrm{l}^{-1}\right)$, VWM of $\mathrm{H}^{+}$did not vary broadly, ranging between $8.0 \mu \mathrm{eq} \mathrm{1}^{-1}$ (April) and $15.5 \mu \mathrm{eq} 1^{-1}$ (January). These rather constant level of $\mathrm{H}^{+}$throughout the year resulted in a larger $\mathrm{H}^{+}$flux during the wet season months of Jan-May in comparison to the dry season (Aug-Oct) (except for November). This is an important result because, given the clear signature of biomass burning in aerosols, an increase in acidity during the dry season associated to the biomass-burning source was expected.

In the same figure it is shown the annual cycle of $\mathrm{SO}_{4}^{2+}$, $\mathrm{NO}_{3}^{-}$, Acetate $\left(\mathrm{Ac}^{-}\right)$and Formate $\left(\mathrm{Fo}^{-}\right)$. It is possible to observe that the VWM of the mineral acidity anions $\mathrm{SO}_{4}^{2+}$, $\mathrm{NO}_{3}^{-}$enhanced their concentrations in dry season, which is an evidence of biomass burning influence. However, this enhancement was not observed in deposition rates, as can be seen in the corresponding plots in the right side of the figure. For example, average monthly deposition for Jan-May was $690 \pm 250 \mu \mathrm{eq} \mathrm{m}^{-2}$, which is statistically compatible with the observed average for Aug-Oct of $660 \pm 290 \mu \mathrm{eq} \mathrm{m} \mathrm{m}^{-2}$. This seasonal difference was not observed in VWM of the organic anions $\mathrm{Ac}^{-}$and $\mathrm{Fo}^{-}$, resulting in smaller deposition fluxes of these anions during the dry season.

\section{Sea salt contribution}

$\mathrm{Na}^{+}$is the most important signature for the seasalt contribution. Clearly, VWM of this ion was higher during dry season, as well as for $\mathrm{Cl}^{-}$. Nevertheless, deposition rates for $\mathrm{Na}^{+}$and $\mathrm{Cl}^{-}$did not vary broadly during the year, similarly to most of ions. It is also shown in Fig. 7 the monthly mean $\mathrm{Cl} / \mathrm{Na}$ ratio. It ranged between 1.3-2.1, which is quite close to the $\mathrm{Cl} / \mathrm{Na}$ ratio in seawater $(=1.17)$. It corroborates with the assumption stated in the previous section that elemental $\mathrm{Cl}$ observed in aerosol is predominantly from marine contribution.

\section{Biomass-burning contribution}

With respect to the annual cycle of ions commonly associated to biomass-burning $\left(\mathrm{K}^{+}, \mathrm{SO}_{4}^{2-}\right.$ and $\left.\mathrm{NH}_{4}^{+}\right)$, it is possible to observe that $\mathrm{K}^{+}$and $\mathrm{SO}_{4}^{2-}$ presented higher $\mathrm{VWM}$ concentrations in the 2 nd semester, but did not for deposition rates. For $\mathrm{NH}_{4}^{+}$, even a seasonal difference in VWM was not observed. These results make it difficult to conclude something with respect to the actual influence of biomass burning. It seems that the degree of disturbance in the atmospheric budget of aerosols was enough to result in an elevation of the seasonal VWM concentration of ions but not in deposition, which is the case in urban polluted areas where fluxes are quite higher. Previous studies in Amazonia observed a similar pattern. Forti et al. (2000) performed measurements in the Amapá state, in Northern Amazonia. The authors stated that biomass-burning influenced the composition of precipitation based on the seasonal differences in the VWM of $\mathrm{K}^{+}$, $\mathrm{SO}_{4}^{2-}$, and $\mathrm{Zn}^{+}$. However, similarly to this study, they did not observe differences in seasonal deposition rates.

Thus, we state that the measurements were not conclusive with respect to the influence of biomass burning in precipitation chemistry. A clear signal of biomass-burning should appear both in VWM and deposition. It seems that Balbina is a limit case, influenced by distant sources, whose biomassburning plumes were subject to several physical and chemical processes during its transport. If one considers the VWM as the parameter for decision, there are clear and significant differences comparing $\mathrm{K}^{+}, \mathrm{SO}_{4}^{2+}$ and $\mathrm{Cl}^{-}$. On the other hand, if deposition be considered as the key parameter it is not conclusive.

\section{$\mathrm{Ca}^{+}$}

In aerosols, Ca was mainly associated to soil dust. Due to the lack of other soil dust tracers in our analysis of rainwater, it was not straightforward to connect $\mathrm{Ca}^{+}$to a specific source. As shown below, it was not possible to extract a soil component in the Principal Component Analysis, and $\mathrm{Ca}^{+}$appears in the biogenic and organic acidity components. Nevertheless, comparing the annual cycle of $\mathrm{Ca}$ in aerosols and in rainwater it is possible to observe that 
Table 6. Component loadings resulted from the application of Principal Component Analysis application on the rainwater chemistry data. Loading values smaller than 0.30 were omitted. In the last line, it is shown the cumulative explained variance of the analysis.

\begin{tabular}{llllll|l}
\hline & $\begin{array}{l}\text { Biogenic } \\
\text { +sea-salt }\end{array}$ & $\begin{array}{l}\text { Organic } \\
\text { acidity }\end{array}$ & $\begin{array}{l}\text { Ammonium } \\
\text { oxalate }\end{array}$ & Phosphate & Citrate & COM* \\
\hline $\mathrm{Na}^{+}$ & $\mathbf{0 . 8 9}$ & - & - & & - & 0.97 \\
$\mathrm{Cl}^{-}$ & $\mathbf{0 . 8 7}$ & 0.35 & - & - & 0.92 \\
$\mathrm{SO}^{2-}$ & $\mathbf{0 . 8 5}$ & 0.34 & - & & - & 0.95 \\
$\mathrm{~K}^{+}$ & $\mathbf{0 . 8 3}$ & - & 0.38 & & - & 0.90 \\
$\mathrm{Mg}^{2+}$ & $\mathbf{0 . 7 9}$ & 0.48 & - & - & 0.98 \\
$\mathrm{Ca}^{2+}$ & $\mathbf{0 . 7 6}$ & 0.48 & - & & - & 0.92 \\
$\mathrm{NO}_{3}^{-}$ & $\mathbf{0 . 6 9}$ & $\mathbf{0 . 5 6}$ & - & & - & 0.94 \\
$\mathrm{Acetate}^{+}$ & 0.37 & $\mathbf{0 . 8 4}$ & - & & - & 0.89 \\
$\mathrm{H}^{+}$ & $\mathbf{0 . 5 7}$ & $\mathbf{0 . 7 6}$ & - & & - & 0.94 \\
$\mathrm{Oxalate}^{2}$ & 0.34 & $\mathbf{0 . 5 2}$ & $\mathbf{0 . 5 2}$ & 0.35 & - & 0.80 \\
$\mathrm{NH}_{4}^{+}$ & 0.30 & - & $\mathbf{0 . 9 1}$ & & - & 0.94 \\
$\mathrm{PO}_{3}^{4-}$ & - & - & - & $\mathbf{0 . 9 4}$ & - & 0.98 \\
Citrate & - & - & - & & $\mathbf{0 . 9 7}$ & 1.00 \\
\hline Cumulative & 41 & 62 & 74 & 84 & 93 & \\
variance $(\%)$ & & & & & & \\
\hline
\end{tabular}

*COM is the communality correspondent to the related ionic species.

monthly means variation was smoother in rainwater VWM than in the aerosol concentration, and that deposition rates were smaller during the dry season due to the reduced precipitation volume.

\section{Factor analysis of rainwater measurements}

The results of principal component analysis (PCA) applied to rainwater measurements are shown in Table 6. Five principal components were extracted, explaining $93 \%$ of the original data variability. All components have a biogenic character, and in some cases, the combination of biogenic with other natural processes. The first component in Table 6 represents the biogenic emissions coupled with the large-scale transport of marine aerosol. The marine contribution was identified by the loading values for $\mathrm{Na}^{+}(0.89)$ and $\mathrm{Cl}^{-}(0.87)$, while the high loading for $\mathrm{K}^{+}(0.83)$ was the signature for biogenic (Artaxo et al., 1988, 1990, 1994). A linear relationship between $\mathrm{Na}^{+}$and $\mathrm{K}^{+}(r=0.84, p<0.0005)$ was also observed, which could suggest that $\mathrm{K}^{+}$deposition could be associated to marine contribution. However, the mean observed proportion of $\mathrm{K}^{+} / \mathrm{Na}^{+}$in rainwater $(=0.36)$ was 16 times greater than the seawater ratio $(=0.022)$, indicating that only marine emissions do not explain the $\mathrm{K}^{+}$apportionment and that there are other processes acting, in this case biogenic processes. In this same component, the loading values for $\mathrm{SO}_{4}^{2-}(0.85), \mathrm{Ca}^{2+}(0.76)$ and $\mathrm{Mg}^{2+}(0.79)$ are also observed, an indication that biogenic processes also play an important role on the deposition of these ions. Their correlations with $\mathrm{K}^{+}$were significant $(r=0.86, r=0.79$ and $r=0.85$, all with $p<0.0005$, respectively), corroborating this analysis. Some of the mineral acidity was also related to this component due to the significant loadings observed for $\mathrm{H}^{+}(0.52), \mathrm{NO}_{3}^{-}(0.69)$ and $\mathrm{SO}_{4}^{2-}(0.85)$.

The rainwater chemistry second component corresponds to processes related to acidity in rainwater, in particular the organic fraction. The loading values observed for $\mathrm{H}^{+},(0.76)$ $\mathrm{NO}_{3}^{-}(0.56)$, acetate $(0.84)$ and oxalate $(0.52)$, indicate the presence of nitric, acetic and oxalic acid. These compounds are final products of photochemical and aqueous phase reactions (Khare et al., 1999; Sanhueza et al., 1991; Chebbi e Carlier, 1996). In particular the presence of $\mathrm{NO}_{3}^{-}$and oxalate together in the same component is evidence of the parallel formation pathways related to oxidation processes dependent on $\mathrm{OH}^{-}$levels to which both acids are subject. One should expect that any eventual influence of biomass burning emissions (as observed in fine mode aerosols) would be reflected in this component. However, it is not possible to find any clear evidence of such effect. If this had happened, a significant correlation between $\mathrm{NH}_{4}^{+}$and $\mathrm{SO}_{4}^{2-}$, which are abundantly emitted by biomass burning, should be observed, and this is not the case. Beyond that, the concentrations of acetate and oxalate were comparable to the observed values in remote areas and smaller than typical values observed both in urban (Kawamura et al., 2001) and biomass burning influenced areas (Yoboué et al., 2005).

Most of $\mathrm{H}^{+}$explained variance is associated with the two first factors. In terms of total deposition, they were responsible for $75 \%$ of $\mathrm{H}^{+}$deposition (calculated via APFA). The second component was responsible by $52 \%$ of the whole $\mathrm{H}^{+}$ deposition, while the first factor accounts for $25 \%$ of the $\mathrm{H}^{+}$ deposition, which helps to characterize the acidity in Balbina as organic. This domain of organic over mineral acidity is 
Concentration
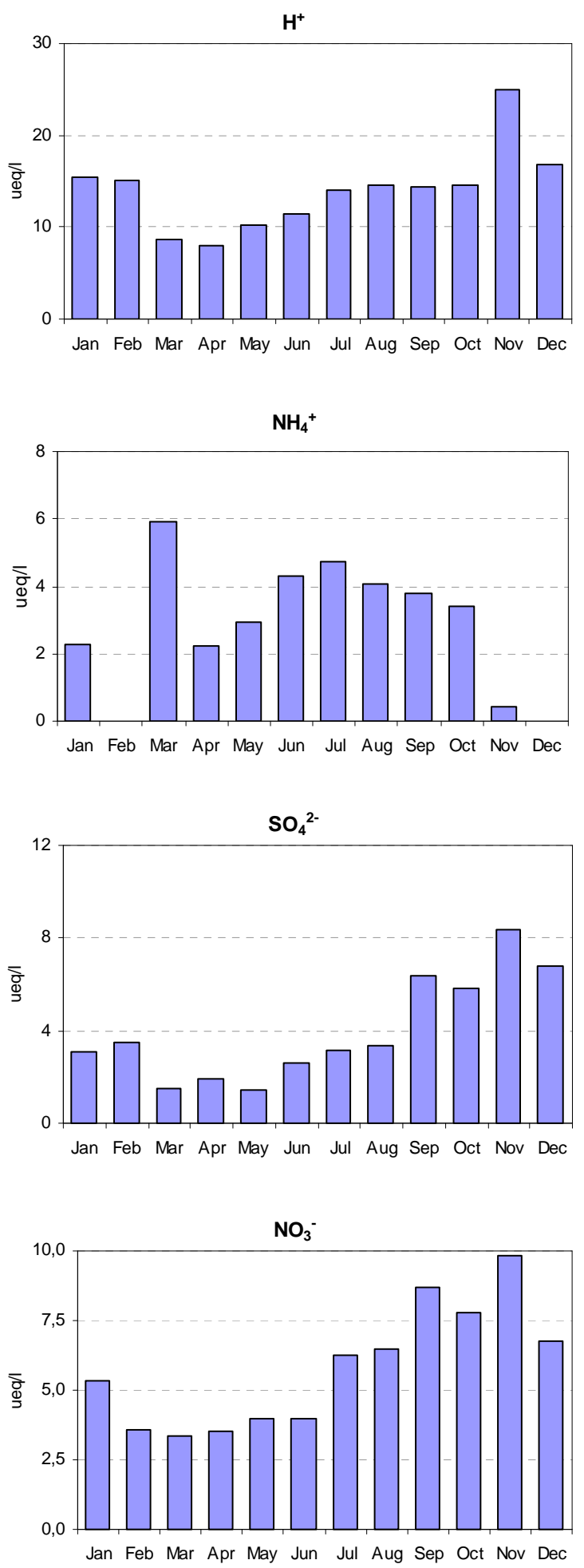

Deposition
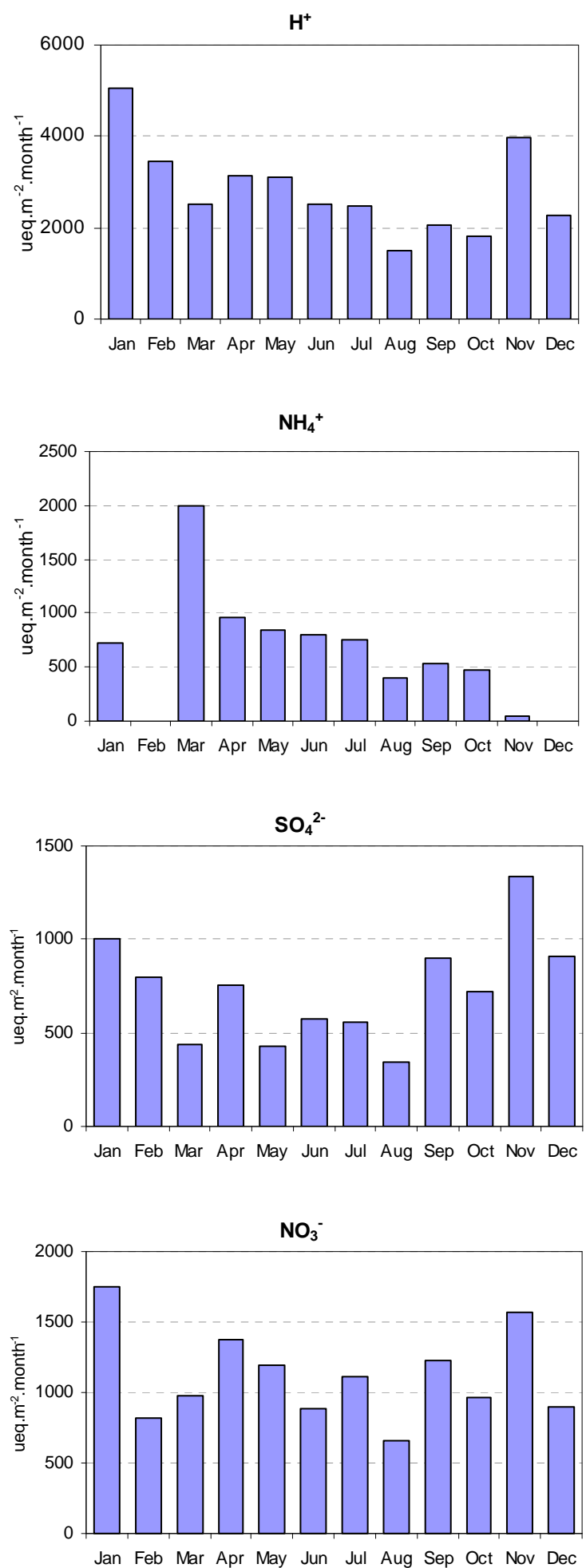

Fig. 7. Monthly means of observed ionic VWM concentration (left) and deposition (right) in rainwater. 


\section{Concentration}

$A c^{-}$

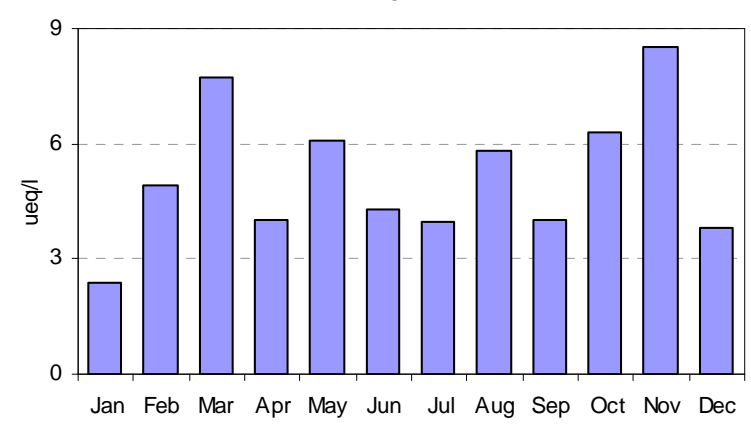

$\mathrm{Fo}^{-}$

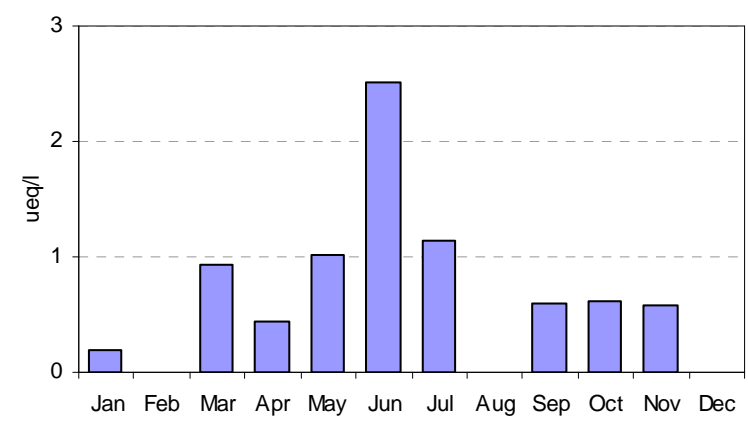

$\mathrm{K}^{+}$

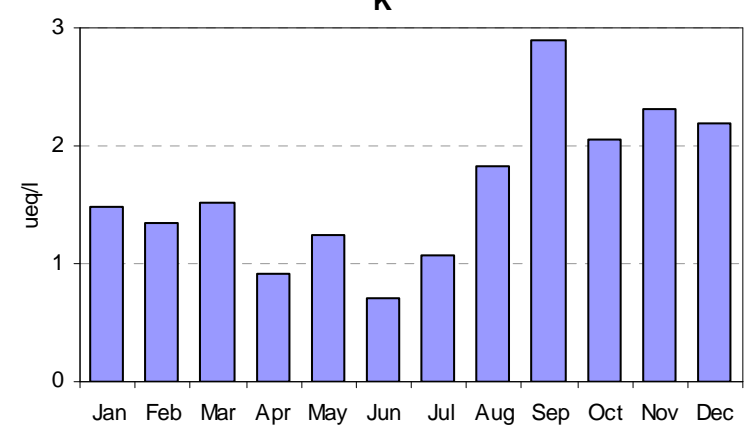

\section{$\underline{\text { Deposition }}$}

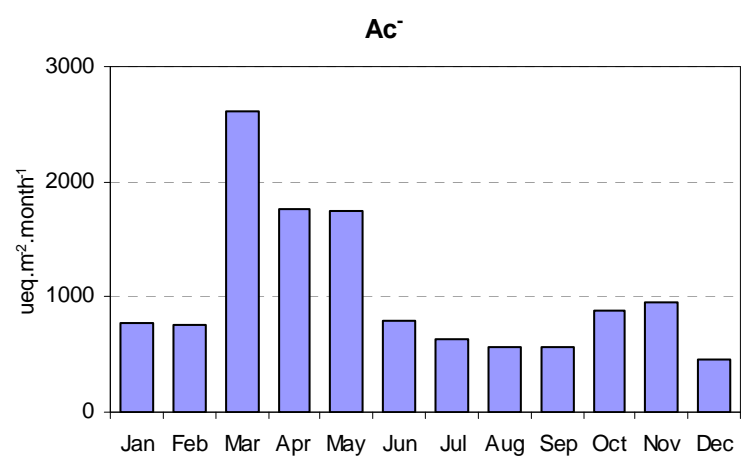

$\mathrm{Fo}^{-}$

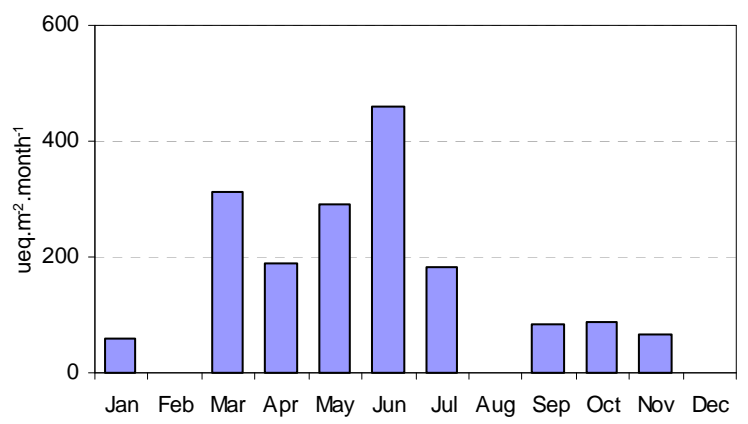

$\mathbf{K}^{+}$

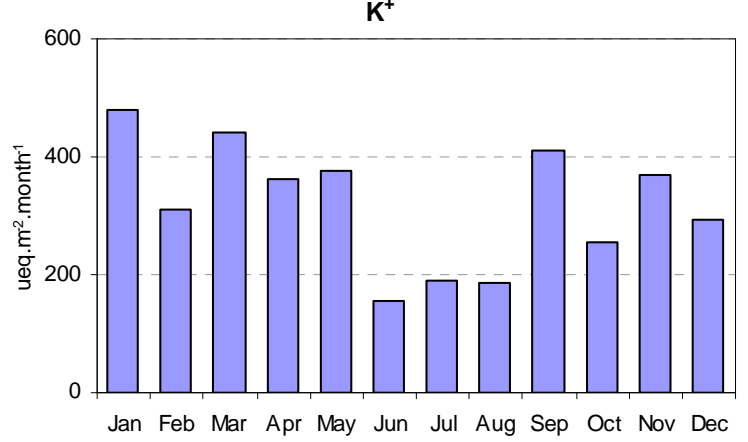

Fig. 7. Continued.

a common feature observed in pristine tropical areas (Sanhueza et al., 1991).

The third component loadings of $\mathrm{NH}_{4}^{+}(0.91)$ and oxalate (0.52) indicate that some fraction of the observed concentration of oxalate was possibly in the form of ammonium oxalate. Another possible explanation is the recombination of $\mathrm{NH}_{4}^{+}$and oxalate after the dissociation of oxalic acid, a buffering effect. Both explanations reside on the availability of $\mathrm{NH}_{4}^{+}$in rainwater, which is an indication of the existence of local mechanisms acting in the production and/or emission of $\mathrm{NH}_{4}^{+}$.

Factors four and five had high loadings only for $\mathrm{PO}_{4}^{3-}$ and citrate, respectively. The identification of components with a single chemical compound is not straightforward because it is not possible to associate them with other more common tracers, as we did in the previously analyzed components. For the fourth component it is possible to do a parallel analysis with aerosol data, where $P$ (predominantly in the coarse mode) is associated with biogenic emissions from the vegetation. The same conclusion can be drawn for rainwater, i.e. the presence of $\mathrm{PO}_{4}^{3-}$ is related to biogenic origin, possibly by the scavenging of biogenic aerosols. However, such an approach could not be done for the fifth component due to the 


\section{Concentration}
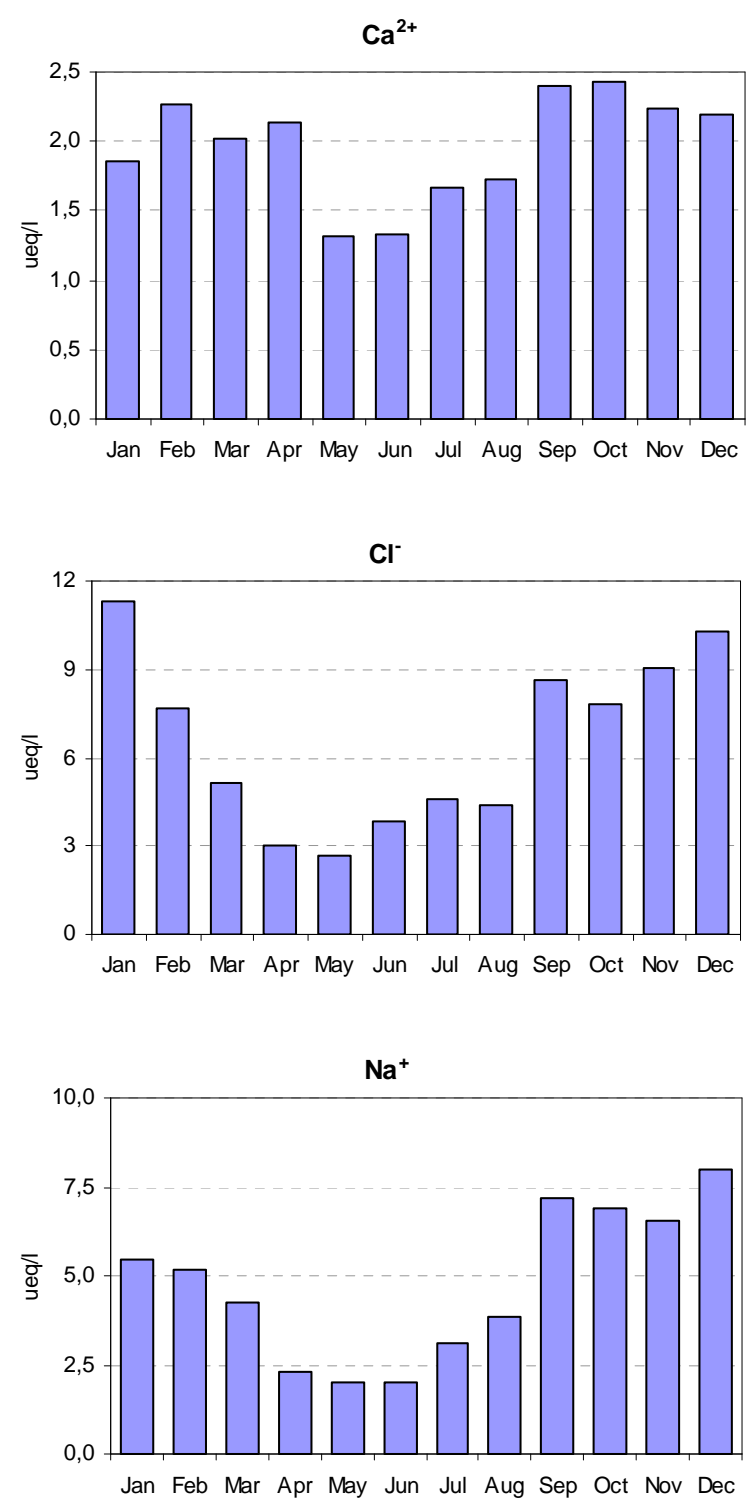

\section{Deposition}
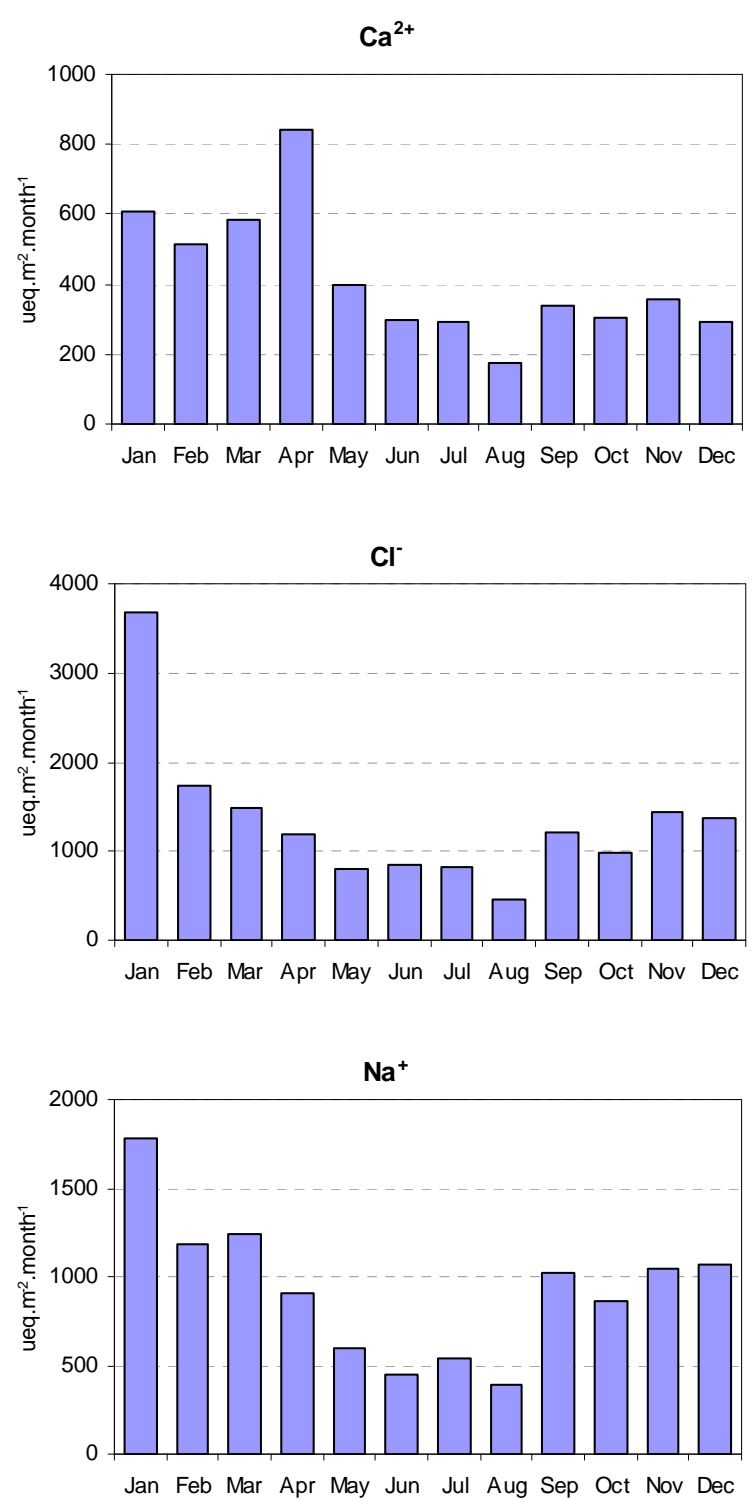

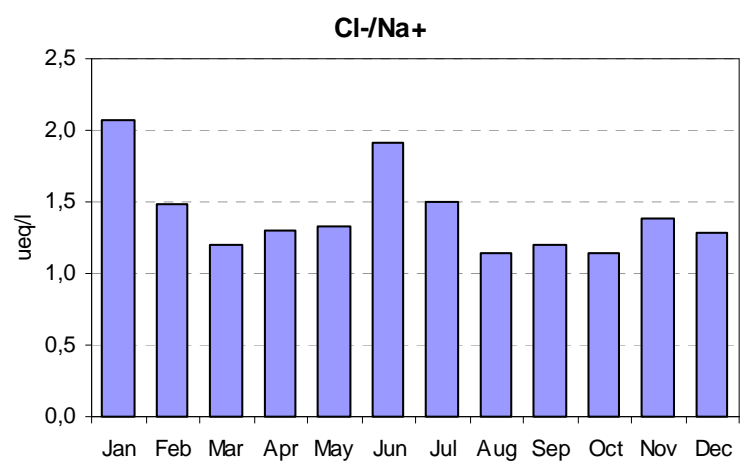

Fig. 7. Continued. 


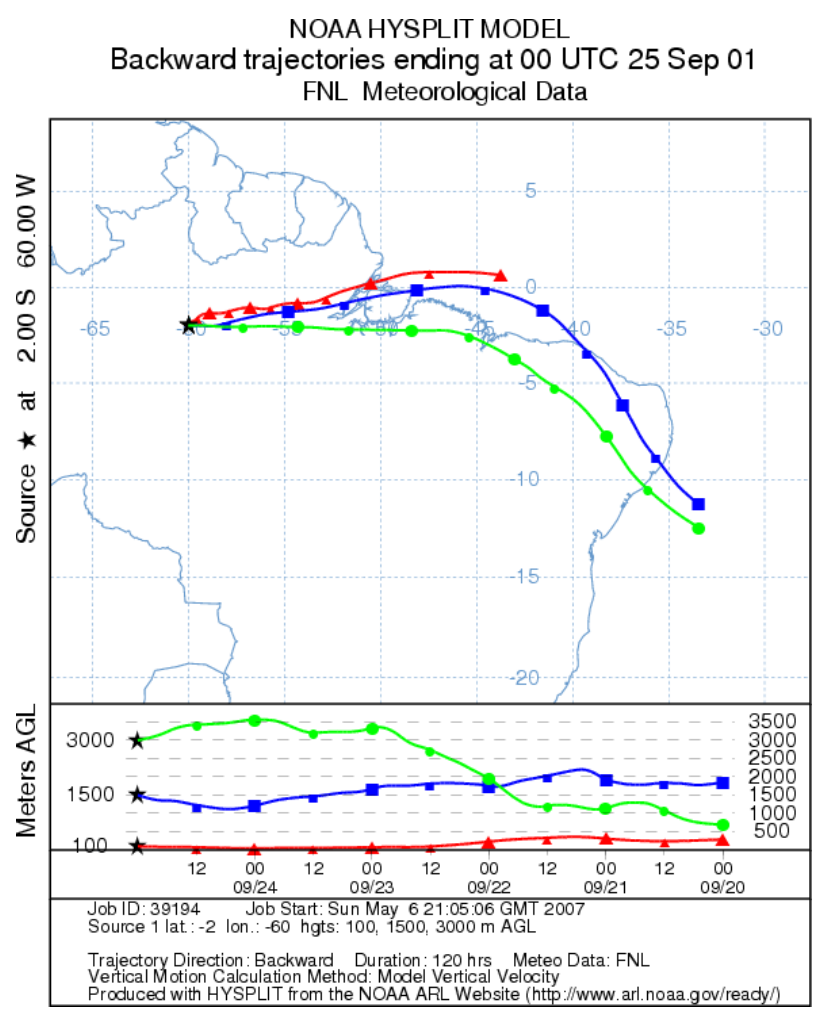

Fig. 8. Hysplit backward trajectories of air masses reaching Balbina at 25 September 2001, when hotspots where observed along the Amazonas river. The resulted wind streamlines are favorable to the transport of biomass-burning plumes to the sampling site.

absence of such measurements of any compound similar to citrate in aerosols.

\section{Discussion and conclusions}

The results and analyses examined in previous sections allow us to comment on several aspects of aerosol and rainwater composition in pristine tropical rainforest areas. The first one is that the composition of aerosols in central Amazonia during the wet season is predominantly of natural biogenic origin, comprising $90 \%$ of coarse mode and $83 \%$ of fine mode aerosol mass.

Biomass burning emission was the second most important contribution to aerosol mass, acting only during the dry season. This influence was mainly due to the large-scale transport of plumes originated in distant locations that spread over huge areas in South America (Andreae et al., 2001; Freitas et al., 2000, 2005). In spite of this effect, central and western Amazonia are regions subject to a minor influence of smoke. In fact, even during the dry season the average $\mathrm{PM}_{10}$ concentration of $8.5 \mu \mathrm{g} \mathrm{m}^{-3}$, which is a pretty low concentration when compared to other heavily impacted areas of Southern Amazonia. This is because plumes of biomass burning typi- cally follow a pathway in agreement with the dominant atmospheric circulation in the period from August to November, the peak of the biomass burning activity. During this period, a counterclockwise atmospheric circulation is established in Central Brazil (Satyamurty et al., 1998), which results in the formation of a preferential corridor where smoke flows to south/southeast of South America. This circulation pattern keeps Western and Central Amazonia relatively free of a significant influence of biomass burning emissions. Apparently, this relative small impact of biomass burning made it impossible to detect a clear signature of biomass burning in the wet deposition fluxes, thought the $\mathrm{VWM}$ of $\mathrm{SO}_{4}^{2-}, \mathrm{NO}_{3}^{-}$and $\mathrm{K}^{+}$, were higher in the dry season. However, the enhancement of these concentrations was not conclusive with respect to the signal of biomass burning because even ions not related to biomass burning also presented higher VWM during the dry season months (e.g. $\left.\mathrm{Na}^{+}\right)$.

Further, factor analysis applied on rainwater data was unable to extract any component related to biomass burning. A linear relationship between $\mathrm{Cl}^{-}$and $\mathrm{K}$ was observed that could be indicative of biomass burning impacts. However, the presence of this relationship also in the wet season makes the identification of most of $\mathrm{Cl}^{-}$and $\mathrm{K}^{+}$as originated from natural biogenic processes.

The chemical composition of precipitation and deposition rates in Balbina is typical of the background composition in remote tropical areas. The majority of components extracted by PCA were associated with natural biogenic emissions. The only exception was the sea-salt contribution (in combination with biogenic) identified as part of the first principal component. PCA analysis for aerosols also extracted a biogenic component during the wet periods that could be separated in two components during the dry season. This separation resulted in a biogenic and in a $\mathrm{Cl}^{-}$associated component, which we attributed to marine contribution.

A linkage between aerosol and rainwater was harder to establish for the remaining components. The main difficulty is that the different analytical methods utilized for aerosols and rainwater resulted in a lack of similar chemical compounds in each analysis. For example, soil dust contribution was not observed in rainwater. It is explained by the absence of a clear soil dust tracer in rainwater as in aerosols (e.g. Al, $\mathrm{Fe}, \mathrm{Ti}$, and $\mathrm{Si}$ ). $\mathrm{Ca}^{2+}$ is crustal but it also has biogenic contributions (Artaxo et al., 1988, 1990). Beyond that, $\mathrm{Ca}^{2+}$ in rainwater appeared in the first component, which is related to biogenic and sea salt and not to soil dust contribution. The main similarity observed in aerosol and rainwater was the marine contribution, which appeared in both analyses. Although it is not significant in terms of the $\mathrm{PM}_{10}$ aerosol mass or deposition rates, it was a clear signal in PCA analysis. The remaining rainwater components could not be associated with aerosols due to the different nature of the assumed processes they represent. For example, the second and third rainwater components, which were associated with acidity and buffering effects, have no parallel effect in aerosols. The 


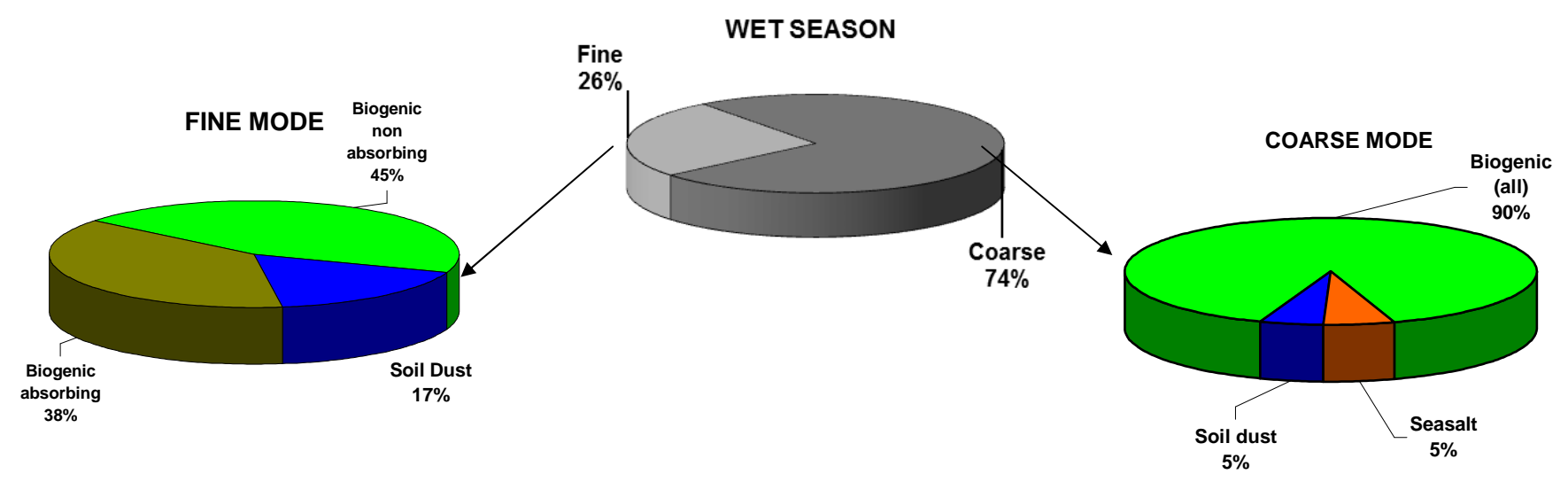

Fig. 9. Final result of Absolute Principal Component Analysis: fine/coarse mode partitioning of aerosol concentration during the 1st semester, and the individual contribution for each extracted principal component. The mean concentrations were $6.6 \pm 2.9 \mu \mathrm{g} \mathrm{m}{ }^{-3}$ for the coarse mode and $2.2 \pm 1.3 \mu \mathrm{g} \mathrm{m}^{-3}$ for the fine mode.

DRY SEASON

FINE MODE
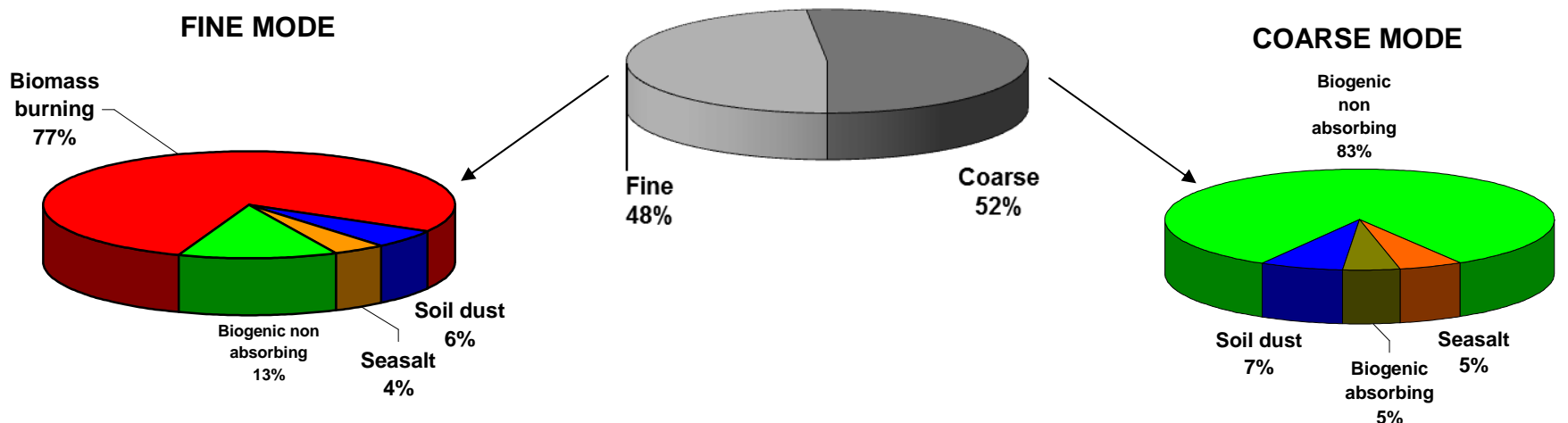

Fig. 10. The same as the previous figure but for the 2 nd semester. The mean concentrations were $7.2 \pm 2.1 \mu \mathrm{g} \mathrm{m}^{-3}$ for the coarse mode and $6.2 \pm 3.1 \mu \mathrm{g} \mathrm{m}^{-3}$ for the fine mode.

same argument is valid for the 5th rainwater component, associated with citrate.

This study describes 2-3 years of continuous measurements of aerosols and rainwater chemistry, showing that the continental Amazonia could be one of the regions where the least anthropogenic influence could be observed in the tropics and temperate regions. It was shown that during the wet season both aerosols and rainwater chemistry are dominated by the biogenic emissions. Biomass-burning plumes advected from other regions of the Amazon starts to have an impact after July. This perturbation extends until December, when the whole basin is in the wet period and biomassburning emissions are negligible in Amazonia. Coarse mode aerosols did not present any significant influence of biomassburning, and its profile could be attributed only to natural biogenic sources. Minimum concentrations of particulate matter and concentrations of non-crustal elemental were typically observed in May. On the other hand, the soil tracers Ti, Fe, Al and $\mathrm{Si}$ clearly presented higher concentrations during the wet season months of Jan-Apr in the fine mode. This pattern was attributed to the long range transport of Saharan dust to the Amazon Basin, which is a phenomenon largely documented.

Rainwater presented a similar profile, with no influence of anthropogenic sources in the wet season. Even the influence of biomass-burning during the dry season was not evident, and could be observed only through the enhancement in the ionic concentration of $\mathrm{K}^{+}$and $\mathrm{SO}_{4}^{2-}$ but not in the corresponding deposition rates. PCA detected at least three processes (the three last components) that are mutually independent and associated with natural processes that deserve further research. With respect to acidity, it was mostly dominated by weak organic acids, especially acetic and formic acids. The proportion acetic:formate was the contrary of the most commonly reported for other remote sites around the world.

It is hard to find sites in Asia and Africa that have little anthropogenic influences, due to the high population density of these continents. Perhaps Amazonia is the last region were 


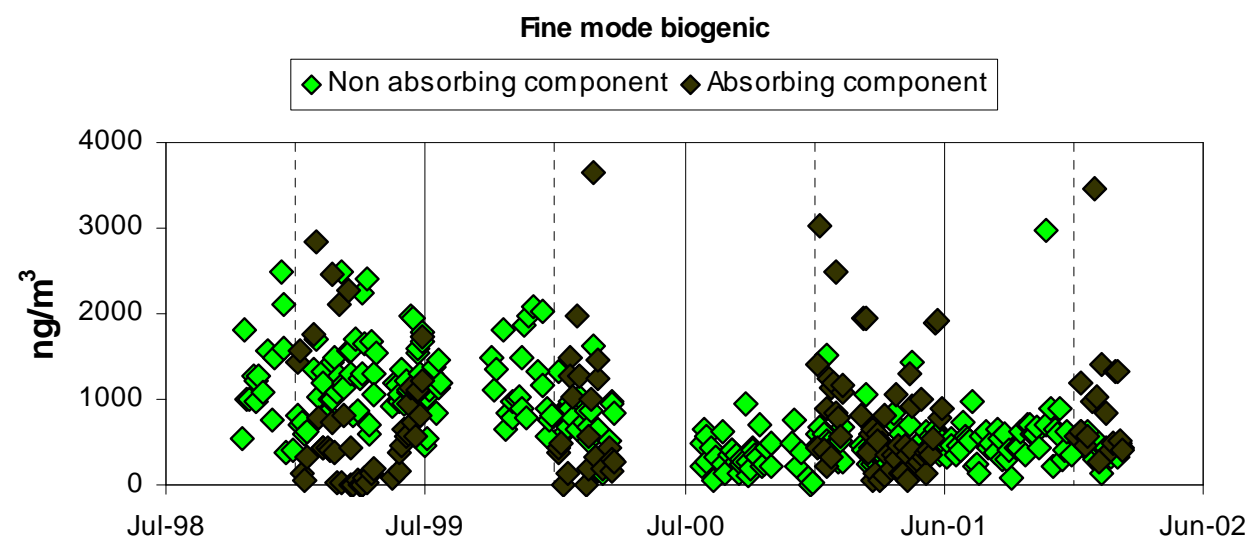

Fine mode soil dust

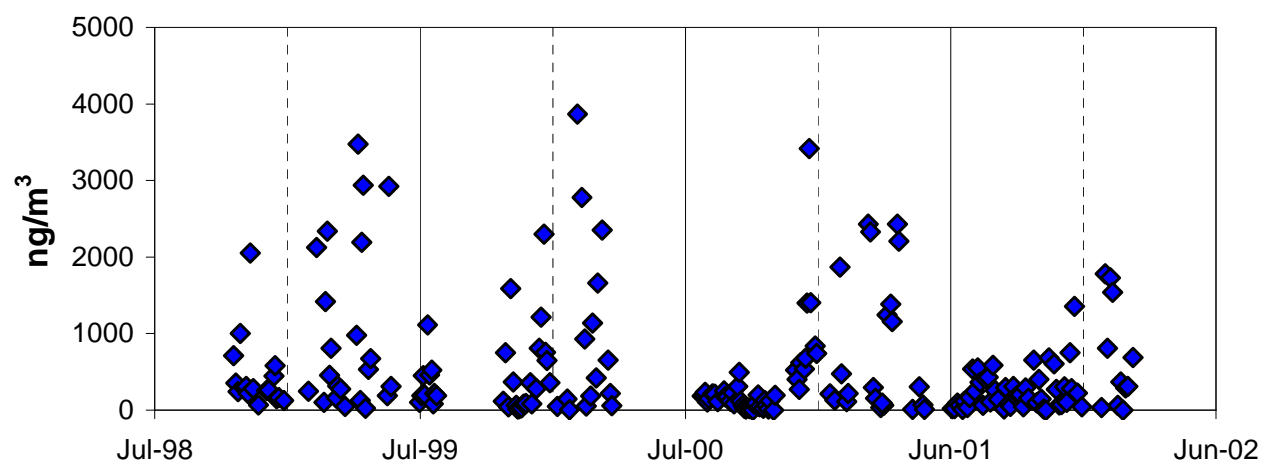

Fine mode biomass burning - DRY SEASON

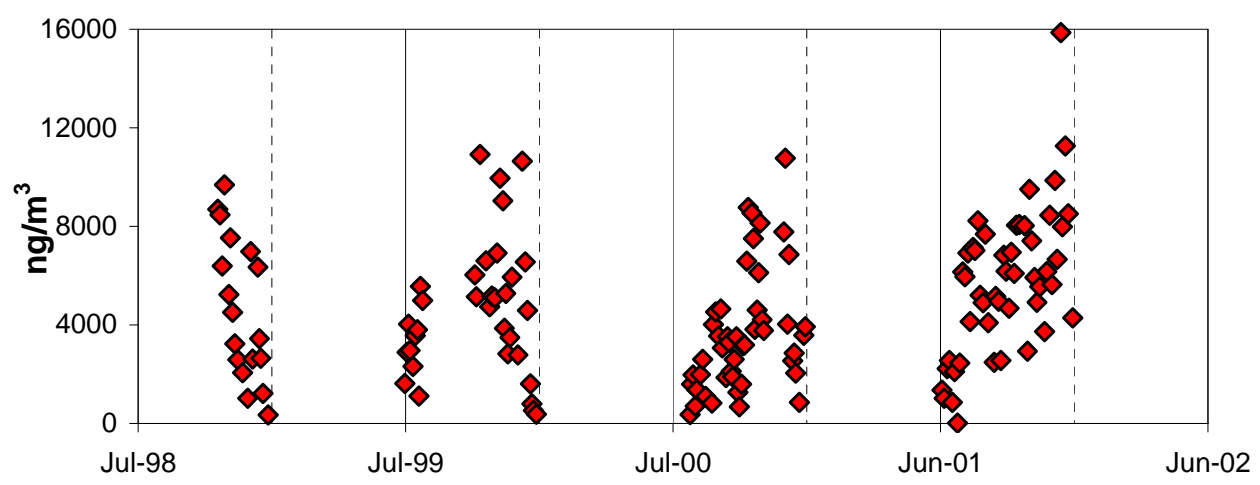

Fig. 11. Absolute concentration of aerosols in the fine mode for each sample, obtained by the APCA technique. Each plot in the figure represents the absolute mass contribution of the identified sources of aerosols: (a) Biogenic contribution, separated in absorbing and nonabsorbing components, (b) Soil dust and (c) Biomass burning (Jul-Dec only).

we still can observe quite pristine atmospheric composition, especially in the tropics.
Acknowledgements. The authors are grateful to Zairon Jose de Mota Nazaré, Mariana Cardoso Silva and Maria Dayse Figueiredo for the sampling collection at Balbina. We thank Alcides Camargo Ribeiro and Ana Lucia Loureiro for the support during sampling and analysis. This research was funded by FAPESP, thematic project AEROCLIMA and CNPq. We thank INPA - Instituto 


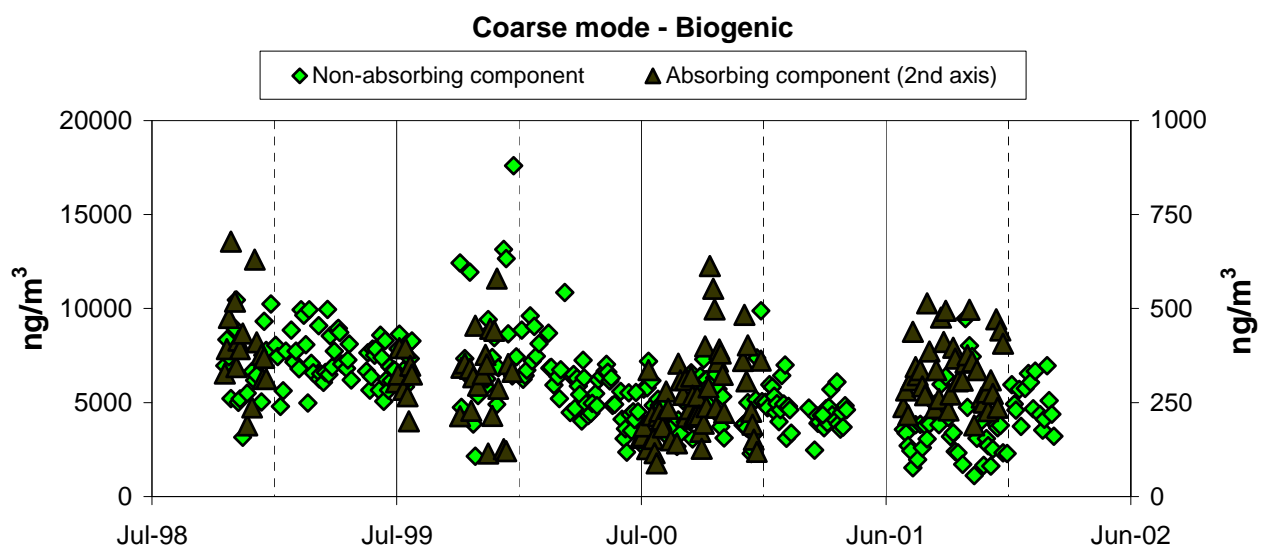

Coarse mode soil dust

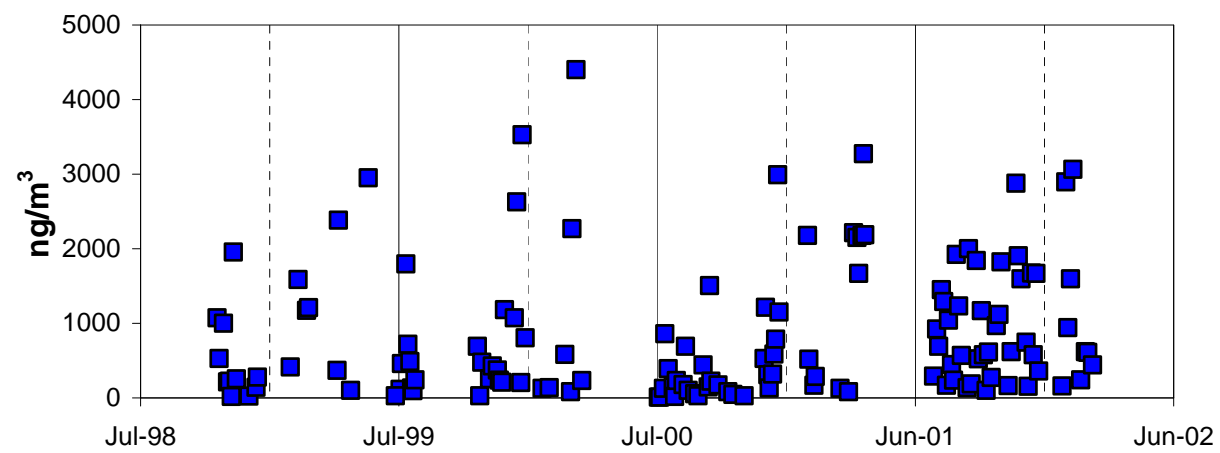

Coarse Mode - sea salt

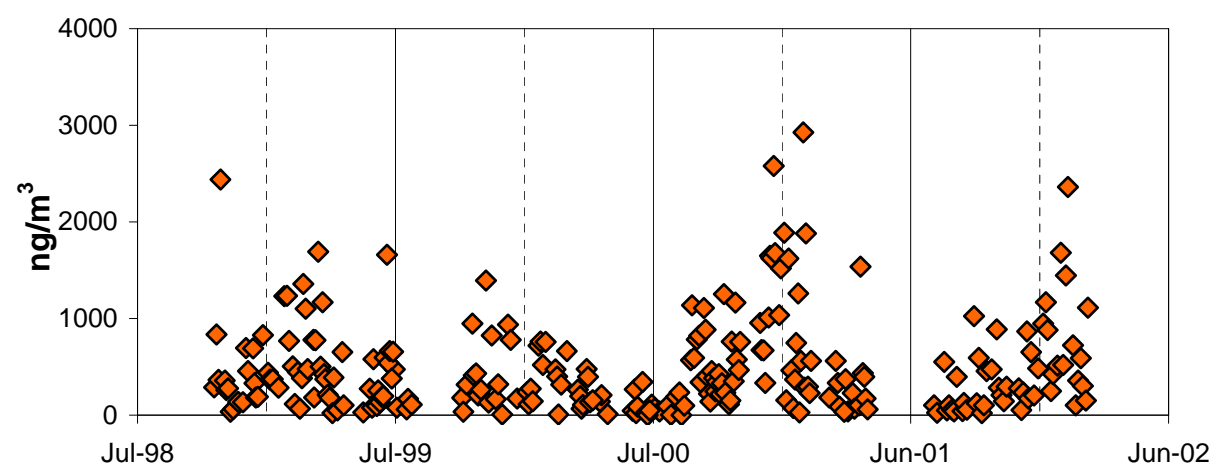

Fig. 12. The same of Fig. 11, but for coarse mode: (a) Biogenic contribution, separated in absorbing and non-absorbing components, (b) Soil dust and (c) Seasalt .

Nacional de Pesquisas da Amazonia for the coordination of the LBA central office and logistical support.

Edited by: A. B. Guenther

\section{References}

Amato, P., Demeer, F., Melaouhi, A., Fontanella, S., Martin-Biesse, A.-S., Sancelme, M., Laj, P., and Delort, A.-M.: A fate for organic acids, formaldehyde and methanol in cloud water: their biotransformation by micro-organisms, Atmos. Chem. Phys., 7, 4159-4169, doi:10.5194/acp-7-4159-2007, 2007.

Andreae, M. O.: Soot carbon and excess fine potassium: Long-range transport of combustion-derived aerosols, Science, 220, 1148- 
1151, 1983.

Andreae, M. O.: Aerosols before pollution, Science, 315, 50-51, 2007.

Andreae, M. O. and Crutzen, P. J.: Atmospheric aerosols: Biogeochemical sources and role in atmospheric chemistry, Science, 276, 1052-1058, 1997.

Andreae, M. O. and Gelencsér, A.: Black carbon or brown carbon? The nature of light-absorbing carbonaceous aerosols, Atmos. Chem. Phys., 6, 3131-3148, doi:10.5194/acp-6-3131-2006, 2006.

Andreae, M. O., Talbot, R. W., Andreae, T. W., and Harris, R. C.: Formic and acetic acid over the central Amazon region, Brazil, 1. Dry season, J. Geophys. Res., 93, 1616-1624, 1988.

Andreae, M. O., Talbot, R. W., Berresheim, H., and Beecher K. M.: Precipitation chemistry in Central Amazonia, J. Geophys. Res. Atmos., 95, 16987-16999, 1990.

Andreae, M. O., Artaxo, P., Fischer, H., Freitas, S. R., Gregoire, J. M., Hansel, A., Hoor, P., Kormann, R., Krejci, R., Lange, L., Lelieveld, J., Lindinger, W., Longo, K., Peters, W., de Reus, M., Scheeren, B., Dias, M. A. F. S., Strom, J., van Velthoven, P. F. J., and Williams, J.: Transport of biomass burning smoke to the upper troposphere by deep convection in the equatorial region, Geophys. Res. Lett., 28, 951-954, 2001.

Andreae, M. O., Artaxo, P., Brandao, C., Carswell, F. E., Ciccioli, P., da Costa, A. L., Culf, A. D., Esteves, J. L., Gash, J. H. C., Grace, J., Kabat, P., Lelieveld, J., Malhi, Y., Manzi, A. O., Meixner, F. X., Nobre, A. D., Nobre, C., Ruivo, M., Silva-Dias, M. A., Stefani, P., Valentini, R., von Jouanne, J., and Waterloo, M. J.: Biogeochemical cycling of carbon, water, energy, trace gases, and aerosols in Amazonia: The LBA EUSTACH experiments, J. Geophys. Res. Atmos., 107, 8066, doi:10.1029/2001JD000524, 2002.

Andreae, M. O., Rosenfeld, D., Artaxo, P., Costa, A. A., Frank, G. P., Longo, K. M., and Silva-Dias, M. A. F.: Smoking rain clouds over the Amazon, Science, 303, 1337-1442, 2004.

Ansmann, A., Baars, H., Tesche, M., Müller, D., Althausen, D., Engelmann, R., Pauliquevis, T., and Artaxo, P.: Dust and smoke transport from Africa to South America: Lidar profiling over Cape Verde and the Amazon rainforest, Geophys. Res. Lett., 36, L11802, doi:10.1029/2009GL037923, 2009.

Artaxo, P.: The atmospheric component of biogeochemical cycles in the Amazon Basin. in: The biogeochemistry of the Amazon Basin, 42-52, edited by: McClain, M. E., Victoria, R. L., and Richey, J. E., Oxford Univ. Press, 2001.

Artaxo, P. and Hansson, H. C.: Size distribution of biogenic aerosolparticles from the Amazon Basin, Atmos. Environ., 29, 393-402, 1995.

Artaxo, P., Storms, H., Bruynseels, F., Van Grieken, R., and Maenhaut, W.: Composition and sources of aerosols from the Amazon Basin, J. Geophys. Res. Atmos., 93, 1605-1615, 1988.

Artaxo, P., Maenhaut, W., Storms, H., and Van Grieken, R.: Aerosol characteristics and sources for the Amazon Basin during the wet season, J. Geophys. Res. Atmos., 95, 16971-16985, 1990.

Artaxo, P., Fernandes, E. T., Martins, J. V., Yamasoe, M. A., Hobbs, P. V., Maenhaut, W., Longo, K. M., and Castanho, A.: Largescale aerosol source apportionment in Amazonia, J. Geophys. Res. Atmos., 103, 31837-31847, 1998.

Artaxo, P., Martins, J. V., Yamasoe, M. A., Procopio, A. S., Pauliquevis, T. M., Andreae, M. O., Guyon, P., Gatti, L. V., Leal,
A. M. C.: Physical and chemical properties of aerosols in the wet and dry seasons in Rondonia, Amazonia, J. Geophys. Res. Atmos., 107, 8081, doi:10.1029/2001JD000666, 2002.

Baars, H., Ansmann, A., Althausen, D., Engelmann, R., Artaxo, P., Pauliquevis, T., and Souza, R.: Further evidence for significant smoke transport from Africa to Amazonia, Geophys. Res. Lett., 38, L20802, doi:10.1029/2011GL049200, 2011.

Barth, M., McFadden, J. P., Sun, J. L., Wiedinmyer, C., Chuang, P., Collins, B., Griffin, R., Hannigan, M., Karl, T., Kim, S. W., Lasher-Trapp, S., Levis, S., Litvak, M., Mahowald, N., Moore, K., Nandi, S., Nemitz, E., Nenes, A., Potosnak, M., Raymond, T. M., Smith, J., Still, C., and Stroud, C.: Coupling between land ecosystems and the atmospheric hydrologic cycle through biogenic aerosol pathways, B. Am. Meteorol. Soc., 86, 1738-1742, 2005.

Ben-Ami, Y., Koren, I., Rudich, Y., Artaxo, P., Martin, S. T., and Andreae, M. O.: Transport of North African dust from the Bodélé depression to the Amazon Basin: a case study, Atmos. Chem. Phys., 10, 7533-7544, doi:10.5194/acp-10-7533-2010, 2010.

Bowman, D. M. J. S., Balch, J. K., Artaxo, P., Bond, W. J., Carlson, J. M., Cochrane, M. A., Antonio, C. M. D., DeFries, R. S., Doyle, J. C., Harrison, S. P., Johnston, F. H., Keeley, J. E., Krawchuk, M. A., Kull, C. A., Brad Marston, J., Moritz, M. A., Prentice, I. C., Roos, C. I., Scott, A. C., Swetnam, T. W., van der Werf, G. R., and Pyne, S. J.: Fire in the Earth System. Science, 324, 481-484, doi:10.1126/science.1163886, 2009.

Bowman, D., Balch, J., Artaxo, P., Bond, W., Cochrane, M., D’Antonio, C., DeFries, R., Johnston F., Keeley, J., Krawchuk, M., Kull, C., Mack, M., Moritz, M., Pyne, S., Roos, C., Scott, A., Sodhi, N., and Swetnam, T.: The human dimension of fire regimes on Earth, J. Biogeogr., 38, 2223-2236, 2011.

Carvalho, L. M. V, Jones, C., and Liebmann, B.: The South Atlantic Convergence Zone: persistence, intensity, form, extreme precipitation and relationships with intraseasonal activity, J. Climate, 17, 88-108, 2004.

Chebbi, A. and Carlier, P.: Carboxylic acids in the troposphere, occurrence, sources, and sinks: A review, Atmos. Environ., 30, 4233-4249, 1996.

Chen, Q., Farmer, D. K., Schneider, J., Zorn, S. R., Heald, C. L., Karl, T. G., Guenther, A., Allan, J. D., Robinson, N., Coe, H., Kimmel, J. R., Pauliquevis, T., Borrmann, S., Pöschl, U., Andreae, M. O., Artaxo, P., Jimenez, J. L., and Martin, S. T.: Mass spectral characterization of submicron biogenic organic particles in the Amazon Basin, Geophys. Res. Lett., 36, L20806, doi:10.1029/2009GL039880, 2009.

Claeys, M., Graham, B, Vas, G., Wang, W., Vermeylen, R., Pashynska, V., Cafmeyer, J., Guyon, P., Andreae, M. O., Artaxo, P., and Maenhaut, W.: Formation of secondary organic aerosols through photooxidation of isoprene, Science, 303, 1173-1176, 2004.

Davidson, E. A., de Araújo, A. C., Artaxo, P., Balch, J. K., Brown, I. F., da C. Bustamante, M. M., Coe, M. T., DeFries, R. S., Keller, M., Longo, M., Munger, J. W., Schroeder, W., Soares-Filho, B. S., Souza Jr., C. M., and Wofsy, S. C.: The Amazon Basin in Transition, Nature, January 2012.

Davidson, E. A. and Artaxo, P.: Globally significant changes in biological processes of the Amazon Basin: results of the Largescale Biosphere-Atmosphere Experiment, Global Change Biol., 10, 519-529, 2004. 
Echalar, F., Artaxo, P., Martins, J. V., Yamasoe, M., Gerab, F., Maenhaut, W., and Holben, B.: Long-term monitoring of atmospheric aerosols in the Amazon Basin: Source identification and apportionment, J. Geophys. Res. Atmos., 103, 31849-31864, 1998.

Elklund, T. J., McDowell, W. H., and Pringle, C. M.: Seasonal variation of tropical precipitation chemistry: La Selva, Costa Rica, Atmos. Environ., 31, 3903-3910, 1997.

Ervens, B., Feingold, G., Frost, G. J., and Kreidenweiss, S. M.: A modeling study of aqueous production of dicarboxylic acids: 1. Chemical pathways and speciated organic mass production, J. Geophys. Res. Atmos., 109, D15205, doi:10.1029/2003JD004387, 2004.

Formenti, P., Andreae, M. O., Lange, L., Roberts, G., Cafmeyer, J., Rajta, I., Maenhaut, W., Holben, B. N., Artaxo, P., and Lelieveld, J.: Saharan dust in Brazil and Suriname during the LargeScale Biosphere-Atmosphere Experiment in Amazonia (LBA)Cooperative LBA Regional Experiment (CLAIRE) in March 1998, J. Geophys. Res., 106, 14919-14934, 2001.

Forti, M. C., Melfi, A. J., Astolfo, R., and Fostier, A.-H.: Rainfall chemistry composition in two ecosystems in the northeastern Brazilian Amazon (Amapá State), J. Geophys. Res., 105, 2889528905, doi:10.1029/2000JD900235, 2000.

Freitas, S. R., Dias, M. A. F. S., Dias, P. L. S., Longo, K. M., Artaxo, P., Andreae, M. O., and Fischer H.: A convective kinematic trajectory technique for low-resolution atmospheric models, J. Geophys. Res. Atmos., 105, 24375-24386, 2000.

Freitas, S. R., Longo, K. M., Dias, M. A. F. S., Dias, P. L. S., Chatfield, R., Prins, E., Artaxo, P., Grell, G. A., and Recuero, F. S.: Monitoring the transport of biomass burning emissions in South America, Environ. Fluid Mech., 5, 135-167, 2005.

Fuzzi, S., Decesari, S., Facchini, M. C., Cavalli, F., Emblico, L., Mircea, M., Andreae, M. O., Trebs, I., Hoffer, A., Guyon, P., Artaxo, P., Rizzo, L.V., Lara, L. L., Pauliquevis, T., Maenhaut, W., Raes, N., Chi, X., Mayol-Bracero, O. L., Soto, L., Claeys, M., Kourtchev, I., Rissler, J., Swietlicki, E., Tagliavi-ni, E., Schkolnik, G., Falkovich, A. H., Rudich, Y., Fisch G., and Gatti, L. V.: Overview of the inorganic and organic composition of size-segregated aerosol in Rondônia, Brazil, from the biomassburning period to the onset of the wet season, J. Geophys. Res., 112, D01201, doi:10.1029/2005JD006741, 2007.

Galloway, J. N., Keene, W. C., and Likens, G. E.: Processes controlling the composition of precipitation at a remote southern hemispheric location: Torres del Paine National Park, Chile, J. Geophys. Res., 101, 6883-6887, 1996.

Galy-Lacaux, C. and Modi, A. I.: Precipitation Chemistry in the Sahelian Savanna of Niger, Africa, J. Atm. Chem., 30, 319-343, 1998.

Gerab, F., Artaxo, P., Gillett, R., and Ayers, G.: PIXE, PIGE and ion chromatography of aerosol particles from northeast Amazon Basin, Nucl. Instr. Meth. Phys. Res. Section B-Beam Interactions with Materials and Atoms, 137, 955-960, 1998.

Gilardoni, S., Vignati, E., Marmer, E., Cavalli, F., Belis, C., Gianelle, V., Loureiro, A., and Artaxo, P.: Sources of carbonaceous aerosol in the Amazon basin, Atmos. Chem. Phys., 11, 27472764, doi:10.5194/acp-11-2747-2011, 2011.

Gillett, R. W. and Ayers, G. P.: The use of thymol as a biocide in rainwater samples, Atmos. Environ. Part A-General Topics, 25, 2677-2681, 1991.
Graham, B., Guyon, P., Maenhaut, W., Taylor, P. E., Ebert, M., Matthias-Maser, S., Mayol-Bracero, O. L., Godoi, R. H. M., Artaxo, P., Meixner, F. X., Moura, M. A. L., Rocha, C., Van Grieken, R., Glovsky, M. M., Flagan, R. C., Andreae, M. O.: Composition and diurnal variability of the natural Amazonian aerosol, J. Geophys. Res. Atmos., 108, 4765, doi:10.1029/2003JD004049, 2003a.

Graham, B., Guyon, P., Taylor, P. E., Artaxo, P., Maenhaut, W., Glovsky, M. M., Flagan, R. C., and Andreae, M. O.: Organic compounds present in the natural Amazonian aerosol: Characterization by gas chromatography - mass spectrometry, J. Geophys. Res. Atmos., 108, 4766, doi:10.1029/2003JD003990, 2003 b.

Gunthe, S. S., King, S. M., Rose, D., Chen, Q., Roldin, P., Farmer, D. K., Jimenez, J. L., Artaxo, P., Andreae, M. O., Martin, S. T., and Pöschl, U.: Cloud condensation nuclei in pristine tropical rainforest air of Amazonia: size-resolved measurements and modeling of atmospheric aerosol composition and CCN activity, Atmos. Chem. Phys., 9, 7551-7575, doi:10.5194/acp-9-75512009, 2009.

Guyon, P., B. Graham, G. C., Roberts, O. L., Mayol-Bracero, W., Maenhaut, P., and Artaxo, M. O.: Andreae, In-canopy gradients, composition, sources, and optical properties of aerosol over the Amazon forest, J. Geophys. Res., 108, D18, 4591, doi:10.1029/2003JD003465, 2003.

Guyon, P., Graham, B., Beck, J., Boucher, O., Gerasopoulos, E., Mayol-Bracero, O. L., Roberts, G. C., Artaxo, P., and Andreae, M. O.: Physical properties and concentration of aerosol particles over the Amazon tropical forest during background and biomass burning conditions, Atmos. Chem. Phys., 3, 951-967, doi:10.5194/acp-3-951-2003, 2003.

Hegg, D. A. and Hobbs, P. V.: Comparisons of sulfate and nitrate production in clouds on the mid-Atlantic and Pacific northwest coasts of the United States, J. Atmos. Chem., 7, 325-333, 1988.

Hegg, D. A., Hobbs, P. V., and Radke, L. F.: Measurements of the scavenging of sulfate and nitrate in clouds, Atmos. Environ., 18, 1939-1946, 1984.

Heymsfield, A. J. and McFarquhar, G. M.: Microphysics of INDOEX clean and polluted trade cumulus clouds, J. Geophys. Res. Atmos., 106, 28653-28673, 2001.

Hoffer, A., Gelencsér, A., Blazsó, M., Guyon, P., Artaxo, P., and Andreae, M. O.: Diel and seasonal variations in the chemical composition of biomass burning aerosol, Atmos. Chem. Phys., 6, 3505-3515, doi:10.5194/acp-6-3505-2006, 2006a.

Hoffer, A., Gelencsér, A., Guyon, P., Kiss, G., Schmid, O., Frank, G. P., Artaxo, P., and Andreae, M. O.: Optical properties of humic-like substances (HULIS) in biomass-burning aerosols, Atmos. Chem. Phys., 6, 3563-3570, doi:10.5194/acp-6-3563-2006, $2006 b$.

Hoffmann, T., Odum, J.R., Bowman, F., Collins, D., Klockow, D., Flagan, R. C., and Seinfeld, J. H.: Formation of organic aerosols from the oxidation of biogenic hydrocarbons, J. Atmos. Chem., 26, 189-222, 1997.

Hoffmann, T., Bandur, R., Marggraf, U., Linscheid, M., Molecular composition of organic aerosols formed in the alpha-pinene/O3 reaction: Implications for new particle formation processes, J. Geophys. Res. 103, 25569-25578, 1998.

Hopke, P. K.: Receptor Modeling in Environmental Chemistry, Wiley, New York, USA, 1985. 
Hopke, P. K., Xie, Y., Raunemaa, T., Biegalski, S., Landsberger, S., Maenhaut, W., Artaxo, P., and Cohen, D.: Characterization of the Gent stacked filter unit $\mathrm{PM}_{10}$ sampler, Aerosol Sci. Technol., 27, 726-735, 1997.

Jaenicke, R.: Abundance of cellular material and proteins in the atmosphere, Science, 308, p. 73, 2005.

Kawamura, K., Kasukabe, H., and Barrie, L. A.: Source and reaction pathways of dicarboxylic acids, ketoacids and dicarbonyls in arctic aerosols: one year of observations, Atmos. Environ., 30, 1709-1722, 1996.

Kawamura, K., Steinberg, S., Ng, L., and Kaplan, I. R.: Wet deposition of low molecular weight mono- and di-carboxylic acids, aldehydes and inorganic species in Los Angeles, Atmos. Environ., 35, 3917-3926, 2001.

Keene, W. C., Galloway, J. N., and Holden, J. D.: Measurement of weak organic acidity in precipitation from remote areas of the world, J. Geophys. Res.-Oc. Atm., 5122-5130, 1983.

Keller, M., Bustamante, M., Gash, J., and Dias, P. (Eds.): Amazonia and Global Change, Geophys. Monogr. Ser., 186, AGU, Washington, D.C., 2009.

Khare, P., Kumar, N., and Kumari, K. M.: Atmospheric formic and acetic acids: an overview, Rev. Geophys., 37, 227-248, 1999.

Koren, I., Kaufman, Y. J., Washington, R., Todd, M. C., Rudich, Y., Martins, J. V., and Rosenfeld, D.: The Bodélé depression: A single spot in the Sahara that provides most of the mineral dust to the Amazon forest, Environ. Res. Lett., 1, 014005 , doi:10.1088/1748-9326/1/1/014005, 2006.

Koren, I., Remer, L. A., and Longo, K.: Reversal of trend of biomass burning in the Amazon, Geophys. Res. Lett., 34, L20404, doi:10.1029/2007GL031530, 2007.

Likens, G. E., Keene, W. C., Miller, J. M., and Galloway, J. N.: Chemistry of precipitation from a remote, terrestrial site in Australia, J. Geophys. Res. Atmos., 92, 13299-13314, 1987.

Lim, H. J., Carlton, A. G., and Turpin, B. J.: Isoprene forms secondary organic aerosol through cloud processing: Model simulations, Environ. Sci. Technol., 39, 4441-4446, 2005.

Maenhaut, W., Fernandez-Jimenez, M. T., Rajta, I., and Artaxo, P.: Two-year study of atmospheric aerosols in Alta Floresta, Brazil: Multielemental composition and source apportionment, Nucl. Instr. Meth. Phys. Res. Section B-Beam Interactions with Materials and Atoms, 189, 243-248, doi:10.1016/S0168-583X(01)010503, 2002.

Mahowald, N. M., Artaxo, P., Baker, A. R., Jickells, T. D., Okin, G. S., Randerson, J. T., and Townsend, A. R.: Impacts of biomass burning emissions and land use change on Amazonian atmospheric phosphorus cycling and deposition, Global Biogeochem. Cy., 19, GB4025, doi:10.1029/2005GB002541, 2005.

Marengo, J. A., Liebmann, B., Kousky, V. E., Filizola, N. P., and Wainer, I. C.: Onset and end of the rainy season in the Brazilian Amazon Basin, J. Climate, 14, 833-852, 2001.

Martin, S. T., Andreae, M. O., Althausen, D., Artaxo, P., Baars, H., Borrmann, S., Chen, Q., Farmer, D. K., Guenther, A., Gunthe, S. S., Jimenez, J. L., Karl, T., Longo, K., Manzi, A., Müller, T., Pauliquevis, T., Petters, M. D., Prenni, A. J., Pöschl, U., Rizzo, L. V., Schneider, J., Smith, J. N., Swietlicki, E., Tota, J., Wang, J., Wiedensohler, A., and Zorn, S. R.: An overview of the Amazonian Aerosol Characterization Experiment 2008 (AMAZE08), Atmos. Chem. Phys., 10, 11415-11438, doi:10.5194/acp10-11415-2010, 2010a.
Martin, S. T., Andreae, M. O., Artaxo, P., Baumgardner, D., Chen, Q., Goldstein, A. H., Guenther, A., Heald, C. L., Mayol-Bracero, O. L., McMurry, P. H., Pauliquevis, T., Pöschl, U., Prather, K. A., Roberts, G. C., Saleska, S. R., Dias, M. A. S., Spracklen, D. V., Swietlicki, E., and Trebs, I.: Sources and properties of Amazonian aerosol particles, Rev. Geophys., 48, RG2002, doi:10.1029/2008RG000280, 2010b.

Martins, J. V., Artaxo, P., Liousse, C., Reid, J. S., Hobbs, P. V., and Kaufman, Y. J.: Effects of black carbon content, particle size and mixing on light absorption by aerosol particles from biomass burning in Brazil, J. Geophys. Res., 103, 32041-32050, 1998a.

Martins, J. V., Hobbs, P. V., Weiss, R. E., and Artaxo, P.: Morphology and structure of smoke particles from biomass burning in Brazil, J. Geophys. Res., 103, 32051-32057, 1998 b.

Morton, D. C., Defries, R. S., Randerson, J. T., Giglio, L., Schroeder, W. and Van Der Werf, G. R.: Agricultural intensification increases deforestation fire activity in Amazonia, Glob. Change Biol., 14, 2262-2275, doi:10.1111/j.13652486.2008.01652.x, 2008.

Mphepya, J. N., Pienaar, J. J., Galy-Lacaux, C., Held, G., and Turner, C. R.: Precipitation chemistry in semi-arid areas of Southern Africa: a case study of a rural and an industrial site, J. Atmos. Chem., 47, 1-24, 2004.

Pöschl, U., Martin, S. T., Sinha, B., Chen, Q., Gunthe, S. S., Huffman, J. A., Borrmann, S., Farmer, D. K., Garland, R. M., Helas, G., Jimenez, J. L., King, S. M., Manzi, A., Mikhailov, E., Pauliquevis, T., Petters, M. D., Prenni, A. J., Roldin, P., Rose, D., Schneider, J., Su, H., Zorn, S. R., Artaxo, P., and Andreae, M. O.: Rainforest aerosols as biogenic nuclei of clouds and precipitation in the Amazon, Science, 329, 1513-1516, 2010

Pruppacher, H. R. and Klett, J. D.: Microphysics of clouds and precipitation, 2nd edn., Oxford Press, 1987.

Riley, J. P.: Chemical Oceanography, edited by: Riley, J. P. and Skirrow, G., 1, 2nd edn., 606 pp., Academic Press, London, UK, 1975.

Rissler, J., Swietlicki, E., Zhou, J., Roberts, G., Andreae, M. O., Gatti, L. V., and Artaxo, P.: Physical properties of the submicrometer aerosol over the Amazon rain forest during the wetto-dry season transition - comparison of modeled and measured CCN concentrations, Atmos. Chem. Phys., 4, 2119-2143, doi:10.5194/acp-4-2119-2004, 2004.

Rizzo, L. V., Correia, A. L., Artaxo, P., Procópio, A. S., and Andreae, M. O.: Spectral dependence of aerosol light absorption over the Amazon Basin, Atmos. Chem. Phys., 11, 8899-8912, doi:10.5194/acp-11-8899-2011, 2011.

Roberts, G. C., Andreae, M. O., Zhou, J. C., and Artaxo, P.: Cloud condensation nuclei in the Amazon Basin: "Marine" conditions over a continent?, Geophys. Res. Lett., 28, 2807-2810, 2001.

Roberts, G. C., Artaxo, P., Zhou, J. C., Swietlicki, E., and Andreae, M. O.: Sensitivity of CCN spectra on chemical and physical properties of aerosol: A case study from the Amazon Basin, J. Geophys. Res. Atmos., 107, 8070, Sep-Oct, 2002.

Salati, E. and Vose, P. B.: Amazon Basin - a system in equilibrium, Science, 225, 129-138, 1984.

Sanhueza, E., Arias, M.C., Donoso, L., Graterol, N., Hermoso, M., Martí, I., Romero, J., Rondón, A., and Santana, M.: Chemical composition of acid rains in the venezuelan savannah region, Tellus, 44B, 54-62, 1992. 
Sanhueza, E., Ferrer, Z., and Santana, M.: HCHO and HCOOH in tropical rains, Ambio, 20, 115-118, 1991.

Satyamurty, P., Nobre, C. A., and Silva-Dias, P. L.: Meteorology of the Southern Hemisphere, edited by: Karoly, D. J. and Vincent, D. G., Meteorology of the Southern Hemisphere, Boston: Meteorology Monograph, 27, 119-139, 1998.

Schkolnik, G., Falkovich, A. H., Rudich, Y., Maenhaut, W., and Artaxo, P.: New analytical method for the determination of levoglucosan, polyhydroxy compounds, and 2-methylerythritol and its application to smoke and rainwater samples, Environ. Sci. Technol., 39, 2744-2752, 2005.

Schneider, J., Freutel, F., Zorn, S. R., Chen, Q., Farmer, D. K., Jimenez, J. L., Martin, S. T., Artaxo, P., Wiedensohler, A., and Borrmann, S.: Mass-spectrometric identification of primary biological particle markers and application to pristine submicron aerosol measurements in Amazonia, Atmos. Chem. Phys., 11, 11415-11429, doi:10.5194/acp-11-11415-2011, 2011.

Scott, B. C. and Laulainen, N. S.: Concentration of Sulfate in Precipitation, J. Applied Meteorol., 18, 138-147, 1979.

Sigha-Nkandjou, L., Galy-Lacaux, C., Pont, V., Richard, S., Sighomnou, D., and Lacaux, P.: Rainwater chemistry and wet deposition over the equatorial forested ecosystem of Zoétélé (Cameroon), J. Atmos. Chem., 46, 173-198, 2003.

Silva-Dias, M. A. F., Rutledge, S., Kabat, P., Silva Dias, P. L., Nobre, C., Fisch, G., Dolman, A. J., Zipser, E., Garstang, M., Manzi, A., Fuentes, J. D., Rocha, H., Marengo, J., Plana-Fattori, A., Sá, L., Alvalá, R., Andreae, M. O., Artaxo, P., Gielow, R., and Gatti, L. V.: Clouds and rain processes in a biosphere atmosphere interaction context in the Amazon Region, J. Geophys. Res., 107, 8072-8092, doi:10.1029/2001JD000335, 2002.

Soto-García, L. L., Andreae, M. O., Andreae, T. W., Artaxo, P., Maenhaut, W., Kirchstetter, T., Novakov, T., Chow, J. C., and Mayol-Bracero, O. L.: Evaluation of the carbon content of aerosols from the burning of biomass in the Brazilian Amazon using thermal, optical and thermal-optical analysis methods, Atmos. Chem. Phys., 11, 4425-4444, doi:10.5194/acp-11-44252011, 2011.

Stallard, R. F. and Edmond, J. M.: Geochemistry of the Amazon 1: precipitation chemistry and the marine contribution to the dissolved-load at the time of peak discharge, J. Geophys. Res.Oc. Atm., 86, 9844-9858, 1981.

Swap, R., Garstang, M., and Greco, S.: Saharan dust in the Amazon Basin, Tellus, Ser. B, 44, 133-149, 1992.
Swap, R., Garstang, M., Macko, S. A., Tyson, P. D., Maenhaut, W., Artaxo, P., Kallberg, P., and Talbot, R.: The long-range transport of southern African aerosols to the tropical south Atlantic, J. Geophys. Res. Atmos., 101, 23777-23791, 1996.

Swietlicki, E., Sanjiv Puri, H.-C., Hansson, and Edner, H.: Urban air pollution source apportionment using a combination of aerosol and gas monitoring technique, Atmos. Environ., 30, 2795-2809, 1996

Talbot, R. W., Andreae, M. O., Berresheim, H., Artaxo, P., Garstang, M., Harriss, R. C., Beecher, K. M., and Li, S. M.: Aerosol chemistry during the wet season in central amazonia - the influence of long-range transport, J. Geophys. Res. Atmos., 95, 1695516969, doi:10.1029/JD095iD10p16955, 1990.

Trebs, I., Metzger, S., Meixner, F. X., Helas, G., Hoffer, A., Rudich, Y., Falkovich, A. H., Moura, M. A. L., Silva Jr., R. S., Artaxo, P., Slanina, J., and Andreae, M. O.: The $\mathrm{NH}_{4}+-\mathrm{NO}_{3}{ }^{--} \mathrm{Cl}^{-}-\mathrm{SO}_{4{ }^{--}}$ $\mathrm{H}_{2} \mathrm{O}$ aerosol system and its gas phase precursors at a pasture site in the Amazon Basin: How relevant are mineral cations and soluble organic acids?, J. Geophys. Res.-Atmos., 110, D07303, doi:10.1029/2004JD005478, 2005.

Vitousek, P. M. and Stanford Jr, R. L.: Nutrient cycling in moist tropical forest, Annu. Rev. Ecol. Syst., 17, 137-167, 1986.

Williams, M. R., Fisher, T. R., and Melack, J. M.: Chemical composition and deposition of rain in the central Amazon, Brazil, Atmos. Envir., 31, 207-217, 1997.

WMO 2004 - World Meteorological Organization Global Atmosphere Watch: Report No. 160: Manual For The Gaw Precipitation Chemistry Programme, Guidelines, Data Quality Objectives and Standard Operating Procedures, edited by: Mary A. Allan, prepared by: GAW Precipitation Chemistry Science Advisory Group WMO TD 1251, 2004.

Yoboué, V., Galy-Lacaux, C., Lacaux, J. P., and Silué, S.: Rainwater chemistry and wet deposition over the wet savanna ecosystem of Lamto (Côte d'Ivoire), J. Atmos. Chem., 52, 117-141, 2005.

Zhou, J., Swietlicki, E., Hansson, H. C., and Artaxo, P.: Submicrometer aerosol particle size distribution and hygroscopic growth measured in the Amazon rain forest during the wet season, J. Geophys. Res., 107, 8055, doi:10.1029/2000JD000203, 2002. 